\title{
The Journal of the American School of Classical Studies at Athens
}

\author{
VOLUME 82 \\ $20 \mathrm{I} 3$
}

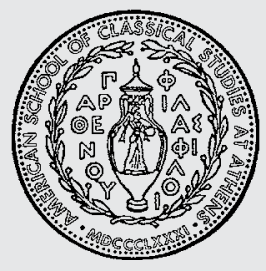

Copyright (C) The American School of Classical Studies at Athens, originally published in Hesperia 82 (2013), pp. 231-261. This offprint is supplied for personal, non-commercial use only. The definitive electronic version of the article can be found at <http://www.jstor.org/stable/10.2972/hesperia.82.2.0231>. 


\title{
HESPERIA
}

\author{
Tracey Cullen, Editor \\ Editorial Advisory Board \\ Carla M. Antonaccio, Duke University \\ Angelos Chaniotis, Institute for Advanced Study, Princeton \\ Jack L. Davis, University of Cincinnati \\ A. A. Donohue, Bryn Mawr College \\ Jan Driessen, Université Catholique de Louvain \\ Marian H. Feldman, University of California, Berkeley \\ Gloria Ferrari Pinney, Harvard University \\ Sherry C. Fox, American School of Classical Studies at Athens \\ Thomas W. Gallant, University of California, San Diego \\ Sharon E.J. Gerstel, University of California, Los Angeles \\ Guy M. Hedreen, Williams College \\ Carol C. Mattusch, George Mason University \\ Alexander Mazarakis Ainian, University of Thessaly at Volos \\ Lisa C. Nevett, University of Michigan \\ Josiah Ober, Stanford University \\ John K. Papadopoulos, University of California, Los Angeles \\ Jeremy B. Rutter, Dartmouth College \\ A.J. S. Spawforth, Newcastle University \\ Monika Trümper, University of North Carolina at Chapel Hill
}

Hesperia is published quarterly by the American School of Classical Studies at Athens. Founded in 1932 to publish the work of the American School, the journal now welcomes submissions from all scholars working in the fields of Greek archaeology, art, epigraphy, history, materials science, ethnography, and literature, from earliest prehistoric times onward. Hesperia is a refereed journal, indexed in Abstracts in Anthropology, L'Année philologique, Art Index, Arts and Humanities Citation Index, Avery Index to Architectural Periodicals, Current Contents, IBZ: Internationale Bibliographie der geistes- und sozialwissenschaftlichen Zeitschriftenliteratur, Numismatic Literature, Periodicals Contents Index, Russian Academy of Sciences Bibliographies, and TOCS-IN. The journal is also a member of CrossRef.

The American School of Classical Studies at Athens is a research and teaching institution dedicated to the advanced study of the archaeology, art, history, philosophy, language, and literature of Greece and the Greek world. Established in 1881 by a consortium of nine American universities, the School now serves graduate students and scholars from more than 180 affiliated colleges and universities, acting as a base for research and study in Greece. As part of its mission, the School directs ongoing excavations in the Athenian Agora and at Corinth and sponsors all other American-led excavations and surveys on Greek soil. It is the official link between American archaeologists and classicists and the Archaeological Service of the Greek Ministry of Culture and, as such, is dedicated to the wise management of cultural resources and to the dissemination of knowledge of the classical world. Inquiries about programs or membership in the School should be sent to the American School of Classical Studies at Athens, 6-8 Charlton Street, Princeton, New Jersey 08540-5232. 
HESPERIA 82 (2OI3)

Pages $23^{-2}-26$

\section{"MOST WORTH REMEMBERING"}

\author{
Pausanias, Analogy, and \\ Clasical Archaeology
}

1. Both the origin and dates of Pausanias are a topic of some debate. The earliest datable events he describes are from the 120s A.D. (Paus. 1.5.5, the addition of the Hadrianis tribe in Athens), and the latest the 170s A.D. (Paus. 8.43.6, but also 5.1.2, Aurelius's victory over German tribes). On Pausanias's dates, see Gurlitt 1890 , pp. 5861; Habicht 1998, pp. 9-12; Bowie 2001, pp. 21-24; Hutton 2005, pp. $9-$ 10; Pretzler 2007b, pp. 8, n. 25, 2324. On Pausanias's origin, see Gurlitt 1890, pp. 56-57; Arafat 1996, p. 8; Habicht 1998, pp. 13-17; Hutton 2005, pp. 9-10.
My thanks to William Hutton and to the anonymous Hesperia reviewers, whose suggestions greatly improved the text; to editor Tracey Cullen and interim editor Mark Landon; and to the attendees at the Norman Baynes Meeting of the United Kingdom Ancient Historians, where a version of this paper was first presented as the keynote address in 2010. I also owe a debt of gratitude to Yannis Lolos and Ben Gourley of the Sikyon Survey Project. Thanks also to Jennifer Baird for reading numerous drafts, and to the thorough Hesperia proofreaders, Eugene McGarry and Nancy Winter, who saved me from many errors. All translations of Pausanias are by W. H. S. Jones (Cambridge, Mass., 1918).

2. On travel in this period, see Marasco 1978, pp. 77-85; Casson 1994, pp. 229-291; Pretzler 2004, 2007a.

"Intellectual pilgrimage" is intended as an inseparable phrase here, emphasizing both the intellectual and religious elements of his travels; note Arafat's discussion (1996, pp. 9-11) of the implication of the word "pilgrim" and his preference for pepaideumenos (learned man), contra Elsner 1992, 2001. See also Jost 2007, pp. 119-120; Pirenne-Delforge 2008, pp. 98-101.

(C) The American School of Classical Studies at Athens 
remarkable account the author produced. This account, whose title survives

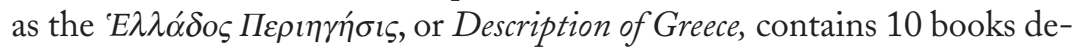
scribing the cities and sanctuaries of the Greek mainland visited by the author, who recorded "a selection of what was" - in his own estimation"most worth remembering" (Paus. 3.11.1).

The survival of Pausanias's work has meant that what he deemed "most worth remembering" has shaped the history, practice, and interpretation of archaeology in Greece. Perhaps more than any other author, Pausanias has governed the way both past and contemporary scholars have conceptualized the archaeology of Classical Greece. Recent studies of Pausanias have rightly highlighted the tension between Pausanias as a literary source and Pausanias as a detached observer of physical landscapes, seeking to subject the Periegesis to the same type of contextualized literary criticism as any other primary source. ${ }^{3}$

Some of the earliest authors who used Pausanias as a guide to the sites of Greece, particularly the 19th-century topographers, tended to view him as if he were an ardent empiricist, who drew on his personal experience of a place to describe it in as accurate a manner as possible. ${ }^{4}$ Recent approaches have become much more nuanced, largely thanks to Christian Habicht's and Paul Veyne's pioneering work in the 1980s, ${ }^{5}$ and have sought to emphasize the value of Pausanias as a literary source and not just as a topographic reporter.

These early interpretations of Pausanias, and indeed his secure place in the archaeological firmament, is partly due to his selectivity and our somewhat nebulous understanding of his motives, the fugitive nature of the author's own voice, and the place of his work within ancient literature. Pausanias's use of an interwoven tripartite structure in his topographical descriptions (his autopsia, theoremata, and logoi, discussed below) has served as a model, in many respects, for modern approaches to past landscapes. Far from being an empiricist, however, Pausanias creates in his text representations or reflections of landscapes through culturally determined grammars; he creates a sense of place rather than a definition of place. In the following pages, I discuss the impact of Pausanias on archaeological modes of thinking and use the example of Sikyon to suggest ways in which the literary reading of the text may be integrated into our understanding of the material remains.

Facets of Pausanias's descriptions of place cohere with modern or early modern topographic experiences, and this fact has allowed Pausanias's text to serve as an analogue within many different studies. Analogy and its correlates can be thought of as understanding the new in terms of the old, the unknown in terms of the known. ${ }^{6}$ Within archaeology, arguing from analogy has long formed a central, if troubling, tool for explaining the material past. Specifically, it has been used by archaeologists as a means of bridging the interpretative gulf between recovered material remains and the constructions of meaning relating to their cultures of origin. ${ }^{7}$ The most common forms of analogy in archaeology are ethnographic analogy and experimental analogy; both are used frequently in interpreting the remains of prehistory, ${ }^{8}$ but have been applied widely throughout archaeological disciplines.

We might even consider Pausanias's own use of ethnography as a form of analogical inference. ${ }^{9}$ Generally, however, Pausanias uses analogies to
3. See, e.g., Habicht 1998; Alcock, Cherry, and Elsner 2001; Akujärvi 2005; Hutton 2005; Pretzler 2007b.

4. As in the example of Col. William Leake (discussed in Wagstaff 2001) and as argued throughout the commentary of Frazer (e.g., 1898, p. 1xix; briefly Elsner 2010a, pp. 163166). This attitude among 19 th-century scholars is explored in Harloe 2010 and MacCormack 2010.

5. Habicht [1985] 1998. Much discussion of Habicht's influence can be found in Elsner 2010a and Harloe 2010. Veyne 1988 is an English translation of the original 1983 French work.

6. Defining analogy precisely can be problematic, especially if one turns to philosophy or history of science, where analogy has long been a highly theorized concept. See Juthe 2005.

7. Wylie 2002, pp. 147-149.

8. Ascher 1961; Wylie 2002, pp. 137-141.

9. On Pausanian ethnography, see Elsner 1994; Alcock 1996; Bowie 1996; Hutton 2005; Luraghi 2008, p. 191. 
explain changes in practice over time, or to project explanation backward through time from his own day. An example of analogy within Pausanias's text can be seen in the case of his explanation of the statue of the Pheidian "Locust" Apollo on the Acropolis (1.24.8):

Opposite the temple is a bronze Apollo, said to be the work of Pheidias. They call it the Locust God, because once when locusts were devastating the land the god said that he would drive them from Attica. That he did drive them away they know, but they do not say how. I myself know that locusts have been destroyed three times in the past on Mount Sipylus, and not in the same way. Once a gale arose and swept them away; on another occasion violent heat came on after rain and destroyed them; the third time sudden cold caught them and they died.

Here, Pausanias is attempting to explain what might have happened in the Athenian past by analogy to his own personal experience in Asia Minor. Analogy is more than just a tool in an explanatory toolkit; it is also a psychological process of acquiring knowledge, providing an individual with different ways of seeing, typifying, and clarifying experience. It is, at its core, about what Itkonen has called "structural similarity." ${ }^{10}$ Pausanias is using the structural similarity between locust swarms on Mount Sipylos and a locust infestation in the Athenian past to explain the dedication of a particular statue only tangentially related to his original experience.

If it is accepted that learning is a largely iterative process of successively approximating the known, then analogy can be understood as a central part of that process. ${ }^{11}$ Within this passage, Pausanias is approximating the "unknown" origin of the statue with the "known" variants of his experiences with locusts. We might consider Pausanias's explanation of these locust swarms as a type of environmental proxy data explaining a past situation in Athens. This passage becomes more than just generalized analogy, it is explanation by reference to proxies or stand-ins drawn from personal experience.

Proxies, or proxy data, are a type of analogy, and are data that indirectly address a specific hypothesis or research question-in other words, they serve as a "delegated" source of information. This is seen most explicitly in archaeology in terms of the reconstruction of ancient environments, whose existence and effects are studied through the proxies of past rainfall, tree ring growth, sedimentation, and so on. Proxies are, by definition, an indirect set of data drawn from a related, but separate, area of inquiry and are not explicitly diagnostic for the object of study. Within contemporary scholarship, they also require interpretation and verification within their own set of criteria before they can be applied to other areas of study. Perhaps most importantly, before conclusions drawn from proxy data can be accepted as reliable, they require supporting evidence from independent lines of inquiry. ${ }^{12}$ In this sense, the use of proxies is a type of analogical reasoning in both Pausanias's text and archaeological thought: the use of the known (for example, tree ring data or locust infestation) to explicate the unknown (climate change in the Holocene, or the dedication of a "Locust" Apollo).

There is a growing body of literature dealing with the inherent caveats of using proxy data for ceramics, palaeoclimatology, and demographic reconstructions within archaeology, yet few people have looked at the use of 
text within classical archaeology as a type of proxy data. ${ }^{13}$ It is frequently the case, however, that text is used in exactly this way, as a type of stand-in or delegated source of information for a particular research question. The examples are numerous, but Vitruvius's impact on the archaeology of the Roman house is perhaps the most obvious.

The earliest excavations of Pompeii, the type site for much of our understanding of Roman domestic space, ${ }^{14}$ drew extensively on Vitruvius's description of the Roman house (6.3.1-11) in order to assign names (and by extension, function) to individual rooms. As noted by Baird, the excavated houses at Pompeii were "treated very much as illustrations of Vitruvius." ${ }^{15}$ Indeed, the terms used in Vitruvius's text have been applied by archaeologists to much of the housing of the Roman world. ${ }^{16}$ The applicability of these textually derived room labels has been reexamined and shown to be largely inappropriate, ${ }^{17}$ not just because the "Vitruvian ideal house" does not exist on the ground, but also because many of the terms used by Vitruvius (such as alae, fauces, cubiculum, and tablinum) to describe Roman housing rarely appear in alternate textual sources.

Allison's extensive work on the topic has shown that many of the prevailing assumptions regarding room function drawn from text are unsupported by material evidence. For example, only six of the 129 spaces traditionally identified as cubicula or bedrooms contained any evidence of beds. ${ }^{18}$ As Allison has written, using textual nomenclature derived from ancient sources is a form of analogical inference that creates the perception that there is a direct correlation between the material remains and the Vitruvian label. ${ }^{19}$ In reality, such inferences tell us more about contemporary scholars' perceptions of the primacy of text and universality of behavior in regard to housing than about any necessary reality of the lived space of Pompeian houses.

Such work highlights the complex and often knotty relationship between text and material culture in the study of the classical past. Where this relationship becomes problematic is when the archaeology is forced to conform to the text, or when texts become interpreted only on the basis of their relationship to real, physical characteristics of their supposed time of origin. Analogy works only so long as the fundamental circumstances producing similarities remain unchanged. Understanding the place of such analogies within contemporary scholarship is important, not only for our understanding of the lived experience of the past, but more generally for challenging assumptions concerning the nature of both the material and textual evidence. Given his central place in the classical archaeology of Greece, Pausanias provides an ideal vehicle for exploring some of these assumptions.

13. E.g., palaeoclimatology: Frenzel, Pons, and Gläser 1991; demography:

Chapman 1999; Grosjean et al. 2003;

ceramics: Greene 2005.

14. Leach 1997, pp. 50-51.

15. Baird 2006, p. 21.

16. Beginning with Mau's “ideal plan," which, in fairness, was only intended to represent features common to houses: Mau 1904, p. 247. A related issue is discussed in Baird 2007, with special reference to Dura Europos.

17. Leach 1997; Allison 1997, 2001, 2004.

18. Allison 1997, pp. 335-336. On cubicula generally, Allison 2004, pp. 161162, 166-167, 176-177.

19. Allison 2001, p. 185. 


\section{THE (AB)USE OF PAUSANIAS}

Contemporary approaches to Pausanias are necessarily colored by the shifting understanding of the place of the Periegesis in the classical tradition. Although he has often been used by archaeologists from the 19th century onward as a descriptive crutch, Pausanias and his work remained on the second tier of primary sources, seemingly as he had been in his own time. The first certain reference to his works in another source is from the 6th century A.D., in the Ethnika of Stephanos of Byzantion. Indeed, it is this source that provides the attribution of the Periegesis to an author named Pausanias. ${ }^{20}$ The work underwent a reevaluation following its transmission to the West in the 15 th century, becoming for scattered Greek communities a basis for the recovery of antiquity and a description of their "twice-lost" homeland. ${ }^{21}$ Pausanias came to hold a central place in the construction of "Greek Antiquity" by antiquarian scholars, serving as both a model for the writing of histories of civilization $^{22}$ and as a means to "visit" the politically charged landscape of Ottoman Greece without the difficulties of having to travel. ${ }^{23}$

Armchair antiquarian interest had become firsthand topographical exploration by the 18th and 19th centuries, and Pausanias was seen as the natural guide to these antiquarian researchers. ${ }^{24}$ The underlying understanding of the author, however, had changed. No longer was he a "universal historian" in the mold of Herodotos or Pliny; by the mid-19th century, Pausanias's work was seen as a plodding description of a now-lost landscape, a work valuable as a repository of topographical and architectural details, but not as a piece of literature. ${ }^{25}$ It was a source to be mined, with places, buildings, myths, and decontextualized content hacked out like silver lodes from the surrounding rock. These nuggets of historical information were imposed onto modern landscapes or understandings as if they were self-evident facts. There was a consistent, if misguided, practice of trying to accommodate the ancient text with the contemporary physical landscape beyond it. Individual passages were cited as analogues of surviving architectural remains, with Pausanias's descriptions used to interpret material remains. ${ }^{26}$ Furthermore, these passages were often used uncritically to fill in the blanks of

20. Steph. Byz., s.v. Aijovía (p. 50,

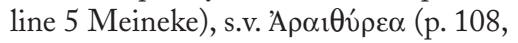
line 16 Meineke), s.v. $\Sigma \varphi \alpha \kappa \tau \eta \rho i ́ \alpha$ (p. 594, line 23 Meineke). For brief summaries, see Akujärvi 2005, p. 1, n. 4; Guilmet 2007. For more depth, see Diller 1955; Bowie 2001. The notion of an "unread" Pausanias is now considered unlikely: Snodgrass 2003;

Akujärvi 2005, p. 2, n. 5.

21. Tolias 2007, p. 58.

22. As early as the 15 th century the Periegesis was understood as a "history" and its author as a "historian." See Bodin [1566] 1945, pp. 20-24; Ulman and Stadter 1972, p. 261.

23. Spencer 1954, pp. 1-25; Yerasimos 1991, p. 12; Vingopoulou 2004.
Even at this early stage of his transmission, Pausanias served as a stand-in for physical journeys to Ottoman Greece. His text helped shape the cultural production of the post-Byzantine Greek diaspora, and served as a vessel into which the concerns of the age could be poured.

24. Diller 1956, 1957. A nuanced discussion of Pausanias's role in shaping aspects of 19th-century thought can be found in Elsner 2010b and Gaifman 2010, and indeed throughout the special issue of Classical Receptions Journal 2:2 (2010).

25. Ulman and Stadter 1972; Tolias 2007, pp. 61-65. See also Hutton 2005, pp. 190-213.
26. Much has been written about the consequences of this methodology: see Elsner 1992 (on reconstructing religious landscapes and cultural identity from Pausanias's text) and 2001 (on Pausanias as text, with reference to Olympia and books 4 and 5); Osanna 1998 (on Aigeira and Pausanias's methodology) and 2001 (on the organization of Pausanias's description of Corinth in book 2); Alcock 2001 (on book 4 and understandings of Messenia); Piérart 2001 (on Argos and the broader structure of book 2); and Sutton 2001 (on antiquarian - and contemporaryapproaches to religious landscapes at Nemea). This article is greatly indebted to these studies. 
an incomplete material record. For example, the early misidentification of the temple of Hephaistos in Athens as the Theseion was due, in part, to the decontextualized application of Pausanias 1.17.2-3 to the only visible temple in the vicinity of the Agora. ${ }^{27}$

From the days of the Grand Tour to the middle of the 20th century, Pausanias's Periegesis was taken at face value as an eyewitness account of vanished landscapes. Scholarly readings were based on the assumption that Pausanias was an objective and neutral author, somewhat dull and lacking in literary sophistication and not without his flaws, ${ }^{28}$ but ultimately a recorder and not an interpreter. This perceived authorial neutrality allowed scholars to use Pausanias as reportage, and justifed the extraction of smaller passages of text.

\section{LANDSCAPE AND LITERATURE}

A long-standing association exists between classical archaeology and topographical or geographical literature produced in the ancient world. ${ }^{29}$ Much of our understanding of landscapes in the classical world - both urban and rural-is drawn from texts. Textual traditions inform our approaches to physical landscapes, even when those traditions are acknowledged as literary constructs. Pausanias forms an excellent case study for critiquing contemporary archaeological approaches to classical landscapes because of the centrality of the Periegesis in shaping those approaches.

The landscape within Pausanias is one of both spatial and temporal variation - he covers a lot of ground, and he discusses an impressively vast chronological span. Pausanias's text was thought, for a long time, to be an appropriate way of dealing with the perceived "time-depth" problem of the Greek East: urbanism has a much longer history in the east than the west, and texts can provide ways of accessing, compartmentalizing, and marking these different times. ${ }^{30}$

In other words, a careful reading of textual sources provided a way of dealing with the problem (especially as juxtaposed with the western Mediterranean) of the chronological depth of the inhabited landscape. Historical explanation was mapped onto archaeological results as if there were an unproblematic correlation between identifiable historical events and changes in material culture. Corinth stops being inhabited in 146 в.c. because the texts say so, ${ }^{31}$ and the result has been that early archaeologists dated the end of pottery sequences to the historical Mummian destruction. ${ }^{32}$ The preponderance of textual evidence relating to Athens gives that polis often

27. The almost willful dismissal of 1.14.6 also contributed to this misidentification. The identification of the Theseion was thought to be supported by the subject of the metopes of the temple; see Emerson 2007, p. 138. The debate, which continued in earnest well into the 1950s, is engagingly summarized by Wycherley (1959). It is worth pointing out (as Mark Landon did to me) that this identification is still not universally accepted; see Koch 1955 , pp. 9-15 (Theseion); Harrison 1977a, p. 139 , n. 14 ; 1977b, pp. 421-426; 1979, p. 220 (Artemis Eukleia).

28. Hutton 2005, pp. 20-29.

29. Dyson 1988; 2006, pp. 79, 251254; Shanks 1996, pp. 49-52. Cf. Habicht [1985] 1998, pp. 70-77.

30. Hodder 1993, pp. 279-280.

31. Strabo 8.6.23, Plut. Phil. 21.1012, Antipater of Sidon (in Greek
Anthology 9.151), among others. On these sources, see Wiseman 1979, pp. 491-494. This and other Corinthian tropes have been convincingly reassessed by Wiseman (1979, pp. 495496), Romano (1993, 1994), and Gebhard and Dickie (2003). On postdestruction occupation, see Millis 2006.

32. E.g., Corinth VII.3, p. 211. See the important discussions in Romano 1993, 1994. 
undue credit in the creation and spread of pottery typologies on the Greek mainland; textual Athenocentrism begat an archaeological Athenocentrism that led to comparisons being equated with influence. Pottery sequences were based on a false authority ultimately derived from text. ${ }^{33}$

The relationship between text and material culture is essentially built upon the ways in which we create and maintain this notion of "authority" within our sources. We ascribe to texts and objects a type of sovereignty over particular ideas or concepts, and this sovereignty is a text's or object's authority. These texts and objects become emblematic of broader notions, and we accept or reject those broader notions based on the level of sovereignty we allow them to possess. Different levels of sovereignty can be contained within any one text or object. A ceramic vessel can be a product of Corinthian clay, it can be a drinking vessel, it can be emblematic of wider social practices related to dining, and it can be a marker of social status or economic prosperity. Each of these "facts" is built upon an acceptance of a certain amount of sovereignty ascribed to that object, based on various criteria. Any one of those "facts" could be rejected without necessarily impinging on the acceptance of other ascribed "facts" (though chains of facts can create more complicated categories of sovereignty). ${ }^{34}$ For material culture, this authority is ascribed by contemporary scholars. For texts, authority is created by the author, often in quite complicated ways. ${ }^{35}$

We can see some of these complications in another 2nd-century context, Lucian's introduction to his Verae historiae (1.2-4):

My readers will be attracted not merely by the novelty of the subject, the appeal of the general design, and the conviction and verisimilitude with which I compound elaborate prevarications, but also by the humorous allusions.... Poets, historians and philosophers of former times wrote much that is miraculous or mythical.... One of these is Ktesias, son of Ktesiochos of Knidos, who wrote about India and its characteristics without seeing it himself or hearing about it from anyone who was telling the truth. ${ }^{36}$

33. An issue discussed by Pemberton in relation to Corinth (2003, esp. pp. 167-169), and more broadly in Shanks 1996, pp. 51-52. Athenocentrism is a long-acknowledged problem, and not one relegated to the past: see Gehrke 1986; Thomas 2000; Herzfeld 2001, pp. 268-273. See also Millett 2000.

34. For notions of sovereignty, see Shanks 1992, pp. 15-46.

35. Howell and Prevenier 2001, pp. 60-68; Marincola 2004, esp. pp. 3$12,128-174$. 2008.

36. Trans. B. P. Reardon, Berkeley

37. Jones 1986, pp. 52-54, 56-58, 61-67; Saïd 1994.

38. Trans. H. L. Jones, Cambridge, Mass., 1917-1923.
In this passage, Lucian is criticizing what he sees as the practice of his predecessors and contemporaries when it comes to establishing their authorial voices and, by extension, their authority. ${ }^{37} \mathrm{~A}$ brief look at Strabo (2.5.11), the Augustan period's geographical author, highlights some interesting comparisons:

And you could not find another person among the writers on geography who has travelled over much more of the distances just mentioned than I; indeed, those who have travelled more than I in the western regions have not covered as much ground in the east, and those who have travelled more in the eastern countries are behind me in the western; and the same holds true in regard to regions towards the south and north. ${ }^{38}$

These quotes have been chosen specifically because they offer such a stark contrast, but even so they offer interesting insights into the nature of the construction of an author's authority. Lucian is aware of the ways in which authority is created by his predecessors and contemporaries, and is satirizing those notions of authority within his own work quite 
explicitly. Strabo is also a self-aware author, mindful of the ways in which "authority" can be created-and he is fully accepting of those methods. He claims that he is the more reliable author because he has seen more of the Mediterranean firsthand than any other author, even if he has not explored individual areas in as much detail as others. ${ }^{39}$ That last fact is an irrelevancy: he has the authority to write about the Mediterranean basin because he has visited most of it, and by making such a claim he is operating in a tradition that can be traced back to Herodotos. ${ }^{40}$ Such writing is not necessarily only about reporting what one has seen, but it is also about composing a work within the grammar of an existing tradition, one that draws on many strands. This grammar is manipulated in order to create claims of authority. As such, descriptions of landscapes and monuments within these works are frequently literary constructs themselves, operating within this grammar. Like Strabo, Pausanias is not recording one actual journey, but a reconstructed sequence of journeys embellished with literary, cultural, sacred, and physical landscapes. ${ }^{41}$ This sequence of journeys provides selective glimpses of those landscapes, not definitive reconstructions.

\section{THE STRUCTURE OF PAUSANIAS}

The grammar that Pausanias used is composed of three main parts:

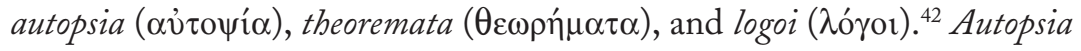
is "seeing for oneself," conducting research as an eyewitness and laying claim to authority because you have physically experienced something. ${ }^{43}$ Theoremata are the sights and logoi are the stories and traditions that Pausanias built his text around ("stories" or "traditions" is perhaps a more accurate translation than the usual "digressions"). ${ }^{44}$ The theoremata, the sights, are the monuments and places Pausanias wished to record, however selectively. ${ }^{45}$ Alhough these passages are frequently called "descriptions" by modern scholars (indeed, as we have seen the work itself is burdened with that title) they are not strictly such. They are springboards for comment, the organizational backbone upon which the logoi are built. ${ }^{46}$ There is a long academic history of arguing over whether or not the theoremata or logoi were the focus of Pausanias's writing, and the prevailing current opinion is that they both held equal importance to the author. ${ }^{47}$

\footnotetext{
39. Engels 1999, pp. 28-32; Pritchett 1999, pp. 11-16; Dueck 2000, pp. 15-30; Pretzler 2007b, pp. 54-55.

40. Elsner 2001, pp. 7-8; Hutton 2005, pp. 190-193; Pretzler 2007b, pp. 44-56.

41. Elsner 2001, pp. 18-20. Literary landscapes: e.g., Paus. 1.28.7, 2.14.2, 2.23.5, 8.14.7, 10.38.5-7; cultural landscapes: e.g., 1.32.3-5, 1.36.1, 2.33.3, 3.14.1, 8.11.7, 9.2.5, 9.11.6, 9.16.5, 9.22.3, 9.25.3, 9.30.2-4, 9.40.10; sacred landscapes: e.g., 1.19.5, 1.22.2, 1.32.2, 1.32.7, 1.35.4, 2.15.5, 2.32.3, 2.35.5, 2.37.5, 3.19.5, 3.20.4, 5.5.11, 5.7.2, 7.23.1, 7.24.7, 8.13.2, 8.17.6, 8.23.4,
}

8.38.6, 8.54.3, 9.3.9, 9.25.1, 10.32.7; physical landscapes: e.g., 1.44.6, 2.11.3, 2.15.2, 2.38.4, 8.6.4, 8.54.5, 10.32.2, 10.32.8, 10.35.8.

42. "Grammar" is meant to be read in a metaphorical, rather than a specific, sense. On the structure of this grammar, see Akujärvi 2005; Pretzler 2007b, pp. 6-14. On Pausanias's language in general, see Hutton 2005, pp. 175-240.

43. Pausanias says this frequently, but most blatantly at 2.22.3. Autopsia need not be relegated only to "seeing," but could be used in a much more general sense. The character of Pausanias's autopsy is discussed in detail in Akujärvi 2005, pp. 90-130. 44. Akujärvi 2005, pp. 6-7. 45. As pointed out by Elsner (2010a, p. 159, n. 7), Pausanias himself varies his criteria for selection: sites are either "worthy of memory" (3.6.5, 3.11.1), "worthy of description" (2.15.1, 2.29.1), or "worthy of seeing" (1.1.3, 3.5.6). See the extensive discussion in Pirenne-Delforge 2008, pp. 97-173, esp. pp. 103-112, 172.

46. On the logoi, see Akujärvi 2005, esp. pp. 42-45; Pirenne-Delforge 2008, pp. 41-95, esp. pp. 41-54, 94-95.

47. Elsner 2001. On the debate, see Akujärvi 2005, p. 7, n. 16. 
It is commonly argued that the order in which these theoremata are introduced is topographically determined..$^{48}$ In other words, Pausanias is assumed to introduce monuments according to the order in which he sees them. There are, of course, many exceptions to this general rule within the Periegesis, and Pausanias is just as likely to abandon topographical order for a thematically determined discussion of monuments. ${ }^{49}$ But running through both the theoremata and logoi is the unifying thread of autopsia, the fact that his text represents the result of his physical inspection. He examines, he researches, he interrogates, and, when applicable, he criticizes, ${ }^{50}$ but most importantly, he is reflecting a tangible, physical reality.

Such ideas can have surprising resonances. Thucydides 1.10 is a good case in point:

For I suppose that if Lakedaimonia should be deserted, and nothing should be left of it but its temples and the foundations of its other buildings, posterity would, after a long lapse of time, be reluctant to believe that their power was as great as their renown. And yet they occupy two-fifths of the Peloponnese and lead the whole, not to speak of their numerous allies in the rest of Hellas. Still, as Sparta is not compactly built as a city and has not provided itself with costly temples and other edifices, but is composed of villages after the old fashion of Hellas, its power would appear less than it is. Whereas, if Athens should suffer the same fate, I suppose that its power would, from what appeared of the city's ruins, seem to be twice as great as it is. ${ }^{51}$

This passage has conditioned contemporary understandings of the topography of ancient Sparta, and was part of the reason the newly independent Greek nation built the modern town on top of the ancient without much forethought in $1834 .{ }^{52}$ For Otto and his subjects, the refounding of Sparta helped ensure a link with the urban West; it consolidated the transition to an urban society by effacing all traces of an embarrassing past, along with reminders of foreign rule, ethnic and religious oppression, and social and economic backwardness; and it restored the nation's historical continuity by connecting the modern kingdom with the ancient world. Perhaps most importantly, it was justified because Thucydides and early-19th-century interpreters of the material remains all agreed on the ephemeral nature of ancient Sparta. Those buildings mentioned by Pausanias and still visible were spared..$^{53}$ The grammar of these discourses was interpreted in a very literal way, allowing for, in the words of Fotiadis, "a past still present, and still vanishing," ${ }^{54}$ and thus a past open to contemporary reinterpretation.

48. Habicht 1998, pp. 20-22; Hutton 2005, pp. 77-82.

49. Pausanias does this, for example, in his description of the altars at Olympia (5.14.4-5.15.12), the courts of Athens (1.28.8-11), and the $\mathrm{Ha}-$ drianic buildings of Athens (1.18.9). On the impact of Pausanias on archaeologists at Olympia, see Jacquemin 2001.

50. For Pausanias on hearing and seeing as sources of knowledge, see

3.25.7, 4.31.5, 5.12.3, 6.6.10-11, 8.10.2, and 9.39.14.

51. Translation adapted from C. F. Smith, Cambridge, Mass., 1919.

52. Hastaoglou-Martinidis 1995 , pp. 107-108.

53. Hastaoglou-Martinidis 1995 , p. 120, n. 25; Wagstaff 2001, pp. 201204. Musti (1996, pp. 33-34) has suggested that Pausanias's description was an explicit attempt to counter Thucydides, though it is interesting to note that Pausanias has to incorrectly date several monuments in order to make his point (3.14.1). See also Waywell and Wilkes 1995.

54. Fotiadis 1995 , p. 74 . He is referring to the University of Minnesota Messenia Expedition, but the sentiment applies broadly. 
Either implicitly or explicitly, many modern studies have absorbed the lessons of Pausanias's grammar and employ it themselves. This approach to autopsia implies that the literary landscape is a direct reflection of a physical landscape - that the works function as a kind of textual panorama that records relative position within a visually and spatially reconstructible place. Pritchett uses these same techniques to lay claim to his own authority, employing a type of pseudo-ethnographic analogy:

[This study] has benefitted from the substantial help of those who have travelled with me.... Some sites have been revisited, and it is possible to expand on earlier studies, as one gains greater familiarity with the terrain. So much depends on the natives from whom one seeks information. ${ }^{55}$

Saïd eloquently highlights how the present and the past can become conflated:

While pretending to throw some light upon classical authors by careful observation of the manners of the present day, romantic travellers succeeded in fact in accommodating reality to their dreams ... by creating for themselves and for their readers carefully edited portraits of modern Greece that transformed the present into the living image of the past. ${ }^{56}$

What Said states about early modern travelers to Greece applies as much to contemporary scholarship as to the authors of the 19th century. We continue to use the grammar of Pausanias, of autopsy, in order to create the authority to interpret material remains. Our often uncomplicated acceptance of authorial claims to authority transforms these literary descriptions of place into proxy data for now-altered physical landscapes. More than that, we (either consciously or otherwise) ape that same grammar of autopsy in order to establish our own textual authority without acknowledging the inherent selectivity of that process.

\section{PAUSANIAS AND CLASSICAL ARCHAEOLOGY}

Our current archaeological understanding of Greece has been dominated by the work of the foreign schools - especially the "big four": the École française d'Athènes, the Deutsches Archäologisches Institut (Athens branch), the American School of Classical Studies at Athens, and the British School at Athens. ${ }^{57}$ These four schools carved out archaeological fiefdoms at the end of the 19th century and made frequent reference to Pausanias in order to do so. ${ }^{58}$ The earliest researches of the French School were focused on finding the sites described by "les Anciens, par Strabon et Pausanias." ${ }^{9}$

55. Pritchett 1985, p. xi.

56. Saïd 2005, p. 291.

57. Hamilakis 2007, p. 50; Loukaki 2008, p. 154.

58. On the histories of the foreign archaeological schools in Greece, see the following. French School (est. 1846):
Radet 1901; Nenna 1996, pp. 11-21; German Archaeological Institute (est. 1874): Jantzen 1986; Marchand 1996, pp. 75-91, 246-248; American School (est. 1881): Lord 1947; Meritt 1984; British School (est. 1886): Waterhouse 1986; Calligas and Whitley
2005. On the structure of foreign schools generally, see Loukaki 2008, pp. 151-156. On Greek "receptions" of the foreign schools, see Hamilakis and Yalouri 1996; Hamilakis 2007, pp. 48-51.

59. Nenna 1996, p. 16. 
Jantzen notes that for the Germans, remains were preserved, restored, and interpreted on the basis of Pausanias (among others). ${ }^{60}$ Similarly, Lord reports that in the American School of the late 19th century, "Herodotus and Pausanias were constantly studied." ${ }^{61}$ Frazer spent a year at the British School collecting material for his commentary, and topography has long occupied a "special place in the work of the School." ${ }^{2}$ Between them, the Schools laid claim to Athens, Corinth, Sparta, Argos, Olympia, and Delphi, among other sites, due to their perceived importance within textual sources.

The standard approach of many of these early archaeological projects was to attempt to either prove or disprove Pausanias's account, and to use those conclusions as the foundation for further study. The French School noted its dismay in not being able to accurately reconstruct the city center of ancient Argos, as they had been frustrated in their attempts to identify the starting point of the periegetes - the sanctuary of Apollo. ${ }^{63}$ The aforementioned debate about the identification of the Hephaisteion in Athens revolved around Pausanias 1.14.6, 1.17.2-3 and the insecure identification of the Stoa Basileios prior to the 1970s. ${ }^{64}$

The best illustration of this approach can perhaps be seen in the work of Eugene Vanderpool and John Travlos, the influential architect of the Athenian Agora, on behalf of the American School (see Fig. 1). Vanderpool was Professor of Archaeology at the School from 1947 to 1971, and Travlos was architect at the Agora from 1935 to 1973 . Over a period of 25 years they revisited the problem of Pausanias's route through the Agora, drawing and publishing plans of Pausanias's route as if Pausanias's literary landscape would map directly onto the archaeological landscape. ${ }^{65}$ They created from the ancient text a visual reconstruction of their interpretation, and by doing so reified the notion that Pausanias was writing about an actual journey rather than creating a pastiche. Travlos and Vanderpool continued to rework the reconstructed route as the American School uncovered more and more of the Agora. Pausanias goes through the Odeion, he goes around the Odeion, he goes straight up the Sacred Way, he doubles back; aspects of his route change, others remain the same. In some respects, it is as though Pausanias were able to respond to the American archaeologists' excavations through Travlos's successive reconstructions. ${ }^{66}$

This approach is not one that can be relegated to the culture-historical archaeological practices of the mid-20th century; this sort of work is still ongoing. For instance, when Guy Sanders wished to reassess the topographical understanding of Pausanias in Sparta, he did essentially the same thing. He examined and critiqued the topographical reconstructions of Pausanias's routes through Sparta proposed by Stibbe, Musti and Torelli, and Kourinou, only to suggest his own version, including a visual reconstruction of Pausanias's journey. ${ }^{67}$

60. Jantzen 1986, pp. 4, 26; cf. Marchand 1996, p. 90.

61. Lord 1947, p. 75.

62. Waterhouse 1986, pp. 10, 130.

63. Nenna 1996, p. 115.

64. Wycherley 1959, pp. 154-156; Agora XIV, pp. 83-90.
65. Vanderpool 1949, p. 130, fig. 1; Agora III, pl. 4; Thompson 1962, fig. 29; and image PD 1988 from the Agora Excavations website, www .agathe.gr (accessed August 26, 2010).

66. Hutton (2005, p. 139) suggests that "the mental images that Pausanias's topographical descriptions impart to readers are often quite different from the physical reality of what he is describing." 67. Sanders 2009, pp. 197, 200, figs. 20.2, 20.3, based on Stibbe 1989; Musti and Torelli 1991; and Kourinou 2000. 


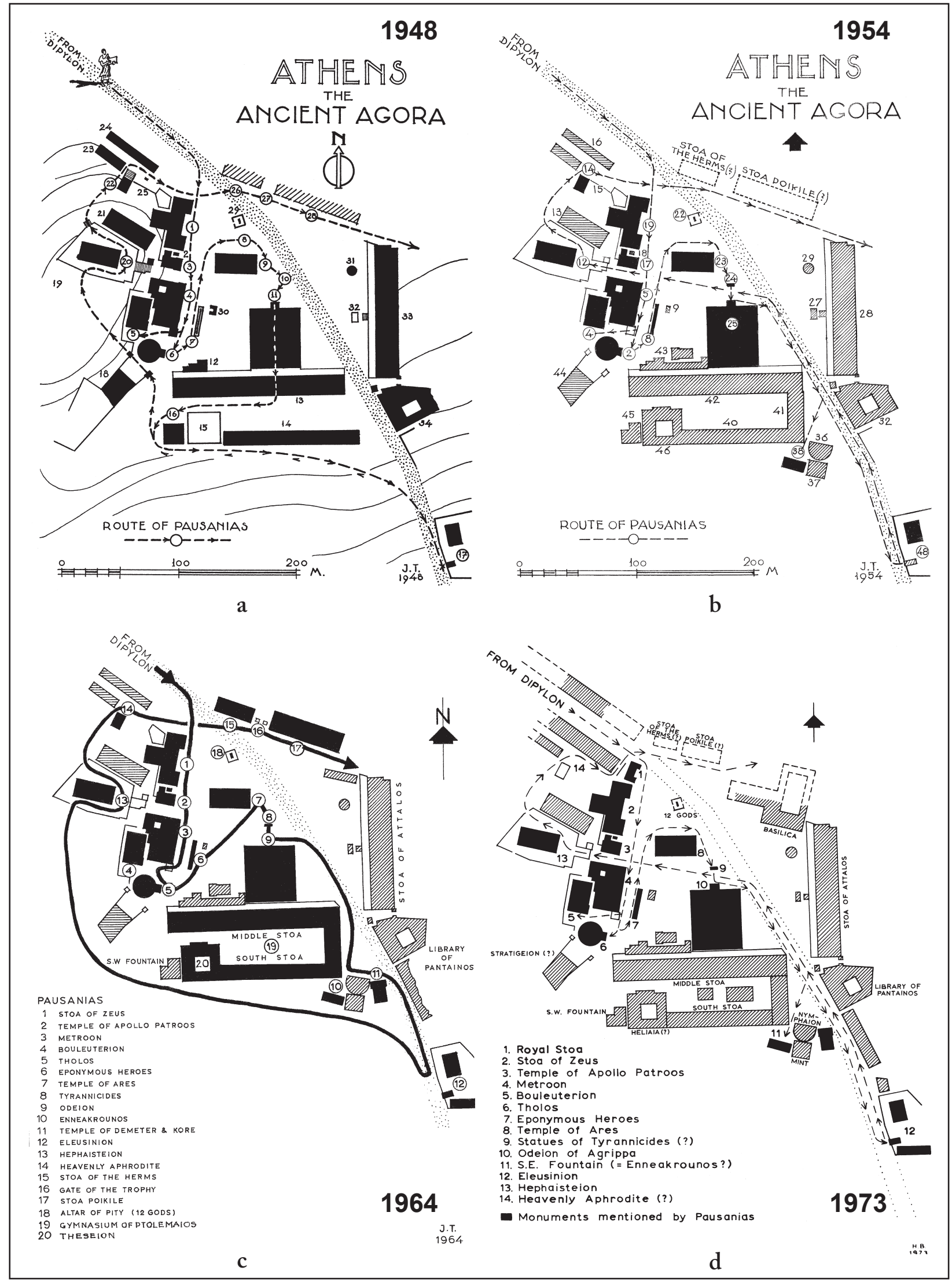


Figure 1 (opposite). Successive reconstructions of Pausanias's route through the Athenian Agora, ca. A.D. 150. After (a) Vanderpool 1949, p. 130, fig. 1; (b) Agora Excavations, PD 862-b; (c) Agora Excavations, PD 1206-1964; (d) Agora III, pl. IV. Courtesy American School of Classical Studies at Athens
68. On the historiography of "accuracy” in Pausanias, see Bultrighini 2001; Hutton 2005, pp. 20-29. Epigraphy is most frequently the field of combat for the debate: see Habicht 1984; Zissa 2006.

As sophisticated as these readings of Pausanias's text may be, they largely miss the broader point: Pausanias creates, in his text, representations or reflections of landscapes through a culturally determined grammar. In other words, he uses the confines of his genre in order to represent landscape in particular ways. By studying modern visual representations of Pausanias's text, we are neither accessing what the landscapes of the past may have been like, nor how those landscapes were conceptualized and perceived in antiquity. By using Pausanias as an analogue for the modern contemporary physical remains, Sanders himself is not accessing how the landscape of Sparta actually was, he is critiquing how it is conceptualized by other scholars. The disconnect between the literary landscape of Pausanias and the contemporary physical landscape is papered over with the assumption that there is an underlying structure of similarity between the physical description and the material remains. When there appears to be a one-toone correlation between the literary landscape and the physical landscape, we read this as Pausanias being correct. Similarly, when there is a disconnect between the literary and the physical, we tend to think that this represents error. ${ }^{68}$ Pausanias's presumed topographic errors are interpreted as errors because he either mistook what he saw or he did not see the thing at all, not because he is writing about something other than an actual landscape ${ }^{69}$ Pausanias's description can be mapped onto the contemporary landscape because he and we have both seen it with our own eyes.

One cannot deny the underlying topographical element of Pausanias's text: he indeed visited many of these places, and it is possible to identify with certainty some of the monuments that he recorded. In this sense, these studies have descriptive value. It is possible, of course, to see value beyond the descriptive. These approaches are important, not because they illuminate the past as it was, but because they illuminate the past as we wish it to be.

\section{PAUSANIAS AND MEMORY}

One of the ways we might place text and archaeology on a similar analytical level is in examining perceptions of cultural memory. ${ }^{70}$ History and geography have long had a close association in ancient text. History can make a place worth seeing; the place can serve as a physical reminder or memorial of an event. ${ }^{71}$ One of the things we can access within the text of the Periegesis is the sense of memory, and what is deemed worth remembering, not only in terms of what the author selects, but in how he frames it.

For Pausanias in particular, we can detect his anxieties about being a Greek in Roman times: he promotes a conscious archaism and has a deliberate preference for religious sites in his travelogue. ${ }^{72} \mathrm{He}$ is deliberately

69. Hutton 2005, pp. 122-125; Pretzler 2007b, pp. 12-13, 40-41.

70. Lafond 2001, pp. 398-402.

71. Porter 2001; Van Dyke and Alcock 2003, pp. 3-6.
72. Elsner 2001; Hutton 2005, pp. 181, 183. On this archaizing trend generally within the Second Sophistic, see Swain 1996, pp. 43-64. 
grounding his contemporary 2nd-century A.D. Roman-ruled Greece within a different construction of time and memory.

As Foucault said, choice of memory is an essential element in any group's perception of itself, making it a point of contestation. Control of social memory bears directly on issues of hierarchy and authority. ${ }^{73}$ There is a reason a temple to Roma and Augustus appears on the Acropolis in a direct relationship with the Parthenon, and there is a reason Pausanias does not mention it. ${ }^{74}$ Within Pausanias's work there are consistent themes of opposition, competing versions of authority, and the use of ritual to create a different, nonlinear, sense of time. Selectively avoiding the temple to Roma and Augustus means Pausanias can create an idealized religious landscape that represents the best of Classical Athens, and avoids the contentious issue of the subjugated Acropolis of his own time.

A mention by Pausanias elevates a monument or object to a status it may never have had in its original context, and a monument's absence creates consternation. ${ }^{75}$ The inverse of this can be seen in the so-called Pylos shield, currently on display in the Agora Museum in Athens (Fig. 2:a). ${ }^{76}$ This shield bears a dedication telling us it was taken from the Lakedaimonians, most likely from the island of Sphakteria in 425 в.с. Pausanias saw such shields displayed in the Stoa Poikile, and from the moment of this shield's recovery in 1936, it has been understood in reference to Pausanias 1.15.4. ${ }^{77}$

We tend to forget, however, that the example currently on display was found in a cistern close to the Hephaisteion (Fig. 2:b), and that it was deliberately deposited there sometime around the beginning of the $3 \mathrm{rd}$ century в.с. ${ }^{78}$ Pausanias could never have seen this shield. But because of the similarity to Pausanias's description, we ignore the biography of this object and the circumstances surrounding its history, and instead graft onto it a history by textual association. This shield, which the periegetes could not have seen, becomes the representative of those shields he did see; it becomes the tangible, physical representation of a literary text, despite the fact that it has its own distinct and separate biography as an object. ${ }^{79}$ In many respects, this shield's history remains buried in the cistern.

The idea of combining history and topography was not new-Polybios had proposed, several centuries earlier, using geography as a means of organizing and understanding history (3.36). Pausanias's descriptions of landscapes, however, frequently seem to deliberately exclude his contemporary present. He focuses on the Classical and Hellenistic monuments, and in some cases he must have been clambering over or standing on later monuments in order to record those of earlier periods. ${ }^{80} \mathrm{He}$ creates a sense of time that has little bearing on either his contemporary present or the past he seeks to record; he creates a new literary time that blends all of those things.

What Pausanias chooses to write about is telling; over the course of his work we can see him emphasizing moments when Greeks united against external threats. ${ }^{81}$ The freedom of the Greeks and their individual cities became a predominant theme in Pausanias's work, in defining what was unique about Greek culture, and what was worth selecting for inclusion in
73. Foucault [1972] 2002, pp. 142148.

74. Shear 1981, p. 363; Hurwit 1999, pp. 279-282.

75. This issue is discussed in detail by Hutton (2005, pp. 150-155) with regard to 2.2.8 and the western end of the Corinthian forum.

76. Agora B262. See images 2008.19.0019 and 2008.19.0020 on the website of the Agora Excavations (www.agathe.gr).

77. Camp 2009, pp. 35-36.

78. Shear 1937, pp. 346-348.

79. For theories of object biographies, see Appadurai 1986; Gosden and Marshall 1999.

80. Porter 2001, pp. 67-76; Pretzler 2007b, pp. 75-76, 91-104.

81. Alcock 1996, pp. 251-260; Swain 1996, pp. 333-338; Habicht 1998, pp. 105-108; Hutton 2005, pp. 63-64, 302-303; Pretzler 2007b, pp. 78-90. 


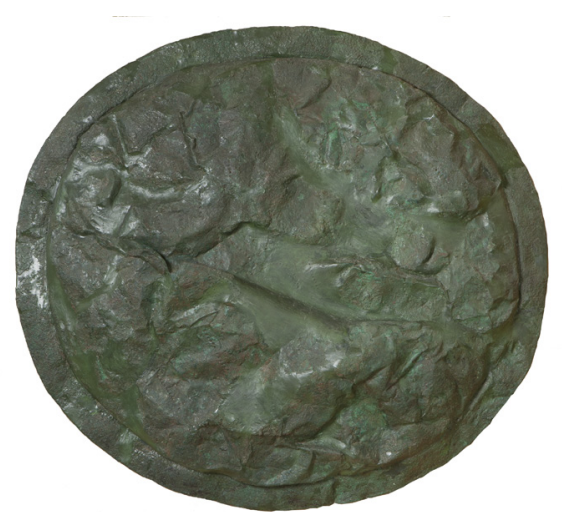

a

Figure 2. (a) The "Pylos shield" (Athens, Agora Museum B262) and (b) the Hephaisteion cisterns where the shield was discovered. Photo C. Mauzy; drawing AgoraPicBk 11, fig. 14. Courtesy American School of Classical Studies at Athens

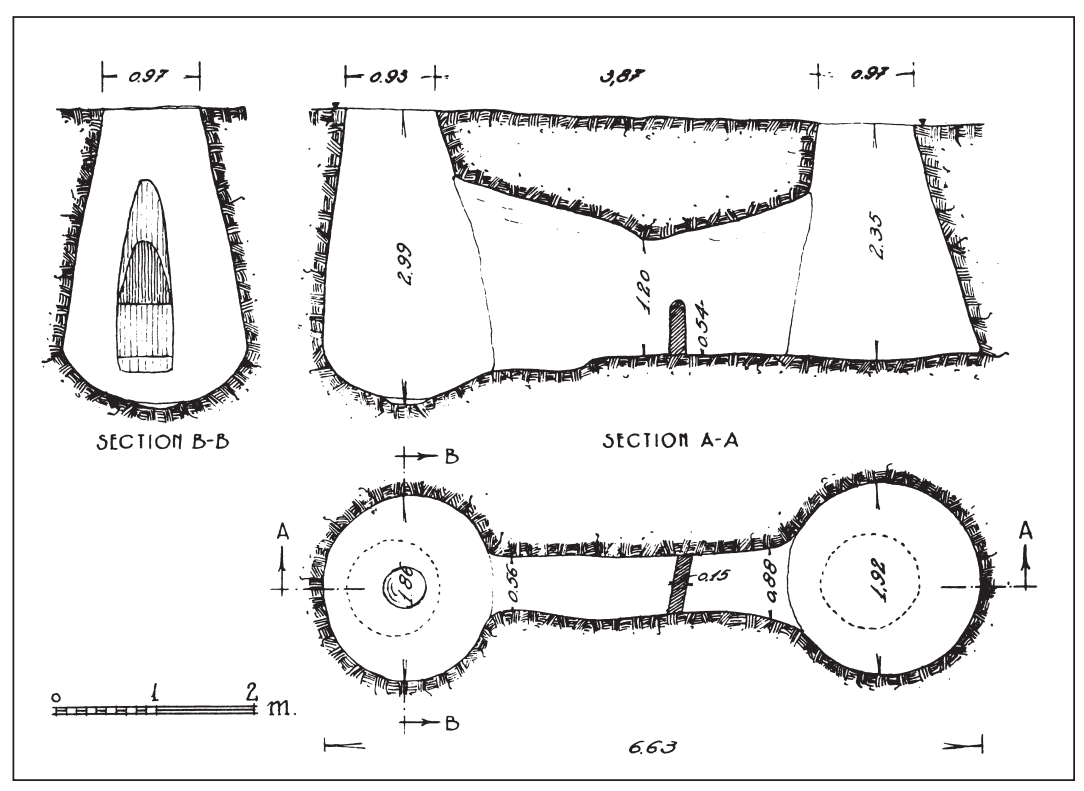

b

his work. His literary landscapes do not present a single set of criteria for defining Greekness, but he does emphasize the importance of places on the Greek mainland for exporting a sense of Greekness to other areas. ${ }^{82}$ This makes them relevant, and essential, to anyone who claimed a part of Greek heritage. His work is less a guidebook to Greece than it is a guidebook to Greekness. ${ }^{83}$

In short, Pausanias's understanding of Greek history has a strong influence on how he frames the contemporary. The past determines for Pausanias what is worth recording, and from this comes a particular sense of identity, and a conflated pastiche sense of time. This is our inheritance from Pausanias's grammar. Thus the historical and mythical framework of many topographic descriptions serves to situate the landscape outside both space and time.

Historians are usually committed to one coherent narrative, but topographers are not historians. ${ }^{84}$ Pausanias's preferred mode of historical writing emphasizes the continuity of the Greek past from a remote antiquity to his own time. Why? His method attempts to highlight the notion that Greece had an unbroken history with perceptible links between his contemporary present, the mythic past, and all points in between: "a land where the remote past was never far away." 85 His depictions give meaning to the landscape, both for Pausanias himself and for his readers; references to the past explain why it is worthwhile to visit these places, and why it is worthwhile to be Greek.

82. See, e.g., Paus. 1.25.3, 1.26.4, 3.7.11, 7.10.1-5, 7.17.1-4, 8.52.1-5, 9.6.5.

83. This point is made more eloquently elsewhere by Elsner
(2001) and Torelli (2001).

84. Marincola 2004, pp. 14-33.

85. Pretzler 2007b, p. 90. See also Bowie 1996, pp. 214-216. 


\section{THE EXAMPLE OF SIKYON}

Sikyon provides an opportunity to examine in specific detail the disjunction between Pausanias and archaeology. Roman Sikyon was a city in the northeastern Peloponnese, the remains of which are situated on an inland plateau. This plateau is $3.5 \mathrm{~km}$ south of the Corinthian Gulf, and lies between the Asopos and Helisson Rivers. It had previously been the acropolis of the Archaic and Classical city, which was itself located on the coast. The archaeological history of Sikyon is spotty at best-most published accounts (which are themselves scarce) focus on individual buildings. ${ }^{86} \mathrm{In}$ Archaic times, when ruled by the Orthagorids, Sikyon was one of the most powerful states of the Greek world and a cradle of the arts. In 303 в.c., Demetrios Poliorketes, son of Antigonos I, destroyed the city in the plain and transferred it to the site of its acropolis on the plateau. The city grew in its new setting during the Hellenistic and Roman periods and witnessed a golden age in the 3rd century B.c. under the general Aratos, head of the Achaian Confederacy.

After the sack of Corinth by Mummius in 146 в.c., Sikyon was granted control over part of Corinth's territory and the presidency of the Isthmian games (Paus. 2.2.2; Strabo 8.381). Roman authors suggest that Sikyon declined from the 1st century B.c. onward-it borrowed money from Atticus (61-59 в.с.), refused to repay, and sold some of its art in 56 в.с. (Plin. $H N$ 35.127). This decline is likely to have been hastened by Corinth's refoundation in 44 B.c. By the time of Pausanias's visit in the 2nd century A.D., Sikyon had suffered an earthquake (Paus. 2.7.1), and much of what he saw was in a ruined condition. But Sikyon continued and continues to be inhabited; although it disappears from textual sources, archaeologically we can see evidence of habitation through the next thousand years. It appears again in sources related to Frankish possessions in the Corinthia of the 13th and 14th centuries, this time under the name of Vasilika or Vasiliko; the latter remains the name of the modern village on the southeast edge of the plateau. ${ }^{87}$

There has been archaeological work on the plateau since the 1880s; the excavation of the theater was carried out sporadically by the American School from 1886 to 1898 while the Americans were trying to decide on a site for a major excavation. ${ }^{88}$ The Greek Archaeological Service undertook excavations from 1920 to 1926 under Alexandros Philadelpheus, and the prolific Anastasios Orlandos (who later rebuilt the Roman bath into the local museum) excavated on the site from 1933 to 1941 and again from 1951 to 1954 . The early work of Philadelpheus and the activity of the American School led to the publication of Skalet's 1928 work, which stood as the only synthesis on Sikyon until Griffin's in $1982 .{ }^{89}$ Rescue excavations on the plateau have been carried out by the Corinthia Ephoreia. ${ }^{90}$ Most

86. This is true, for example, in the case of the theater excavations; see, e.g., McMurtry 1889; Fossum 1905. Lolos's (2011) new synthesis of Sikyon and its territory goes some way to correct this imbalance.

87. Skalet 1928, pp. 6-7; Griffin 1982, p. 6; Lolos 2011, pp. 18, 287-290.
88. See n. 86, above. The School ultimately decided to excavate at Ancient Corinth.

89. An overview of the archaeological history can be found in Skalet 1928; Griffin 1982; Lolos 2011, pp. 272292.

90. These are published in Praktika and Archaiologikon Deltion. Particularly important are Philadelpheus 1926; Orlandos 1935, 1954; Krystalli-Votsi 1984. A full bibliography can be found on the website of the Sikyon Survey Project: http://extras.ha.uth.gr/sikyon/ en/bibliography.asp (accessed August 28, 2010). 
recently, the Sikyon Survey Project, of which I am the field director, has been operating on the plateau since $2004 .{ }^{91}$

Each of these archaeological projects or syntheses has relied on Pausanias to some extent, primarily by seeking to map Pausanias's description (found in 2.5.5-2.11.2) onto visible remains. ${ }^{92}$ This process goes back to Dodwell and Leake, and has essentially continued unabated..$^{93}$ Pausanias's text has long been a proxy for archaeological material on the Sikyonian plateau, but using Pausanias as a proxy for the physical remains begins to break down as soon as we look for and record those physical remains; the text becomes strained and warped as we try to force it into the confines of stone and brick.

\section{LITERARY VERSUS PHYSICAL SIKYON}

The archaeological research on the plateau has led to the polarization of Pausanias's literary landscape and the contemporary physical landscape. In their syntheses, both Skalet and Griffin discuss the archaeology of Sikyon as if it were congruent with the topography described by Pausanias, using his description of the Bouleuterion (2.9.6) as a means of orienting his broader description of the city on top of the recovered archaeological remains. ${ }^{94}$ This serves not only to aid in the identification of the recovered features of the site, but also to fill in the material gaps in the archaeological record. Griffin attempts to securely identify the Archaic acropolis of Sikyon based on the confluence of visible remains and Pausanias's description, ${ }^{95}$ while Skalet interprets fragmentary foundations visible above the theater on the basis of Pausanias's description of the Temple of Fortune (2.7.5) and suggests that the Temple of the Dioskouroi must be located nearby. ${ }^{96}$ Interestingly, Skalet also extends this approach beyond the topography or the structures of the city to the objects, for example, claiming that a bronze statuette in the British Museum is a representation of Lysippos's Zeus from Sikyon's agora (2.9.6). ${ }^{97}$

If, however, one takes into account no information about directions, distances, and relative location other than that given explicitly or clearly implied in Pausanias's text (as far as one can, given the contemporary

91. This project is directed by Yannis Lolos of the University of Thessaly, Volos. The aims of this project have been published in Lolos, Gourley, and Stewart 2007. Annual reports are available online: http://extras.ha.uth.gr/ sikyon/en/index.asp.

92. E.g., American School: McMurtry 1889, pp. 268-269; Fossum 1905, p. 271; Greek Archaeological Service: Philadelpheus 1926; Orlandos 1935, 1954; Krystalli-Votsi 1984; Sikyon Survey Project: Lolos 2005, p. 279 (on Titane and Sikyon); Lolos, Gourley, and Stewart 2007, p. 273.

93. The identification and location of Pausanias's "dripping spring" (2.5.2) is a good example: Dodwell 1819, p. 295; Leake 1830, p. 372; Bursian 1872 , p. 27 , n. 2 ; Frazer 1898 , p. 48; Earle 1889, p. 287; Skalet 1928, pp. 910; Griffin 1982, p. 15, n. 2.

94. Skalet 1928, pp. 7-26; Griffin 1982, pp. 6-24.

95. Griffin 1982, pp. 21-24.

96. Skalet 1928, pp. 10-11. Skalet makes repeated references to Pausanias's text in his discussion of the topography of the plateau: the "portico of Cleisthenes" (p. 17; Paus. 2.9.6); the "Bouleuterium" (pp. 17, 19-20; Paus. 2.9.6); and the "gymnasion," unexcavated in Skalet's day (p. 22; Paus. 2.10.1). He also ties together the physical topography, Pausanias's text, and the iconographic evidence from coin issues in order to create his reading of the topography of the city.

97. Skalet 1928, p. 21, n. 91. The original catalogue number is Bronze 275 , while the current catalogue number is GR 1825.0453.5. The original collector, Richard Payne Knight, thought it was a representation of Lysippos's statue at Olympia; see Clarke and Penny 1982, p. 133; also Walters 1899, p. 36, pl. VII; Swaddling 1979. 
topography and the few indisputable landmarks), a literary topography that only superficially resembles the known physical reality can be produced (Figs. 3, 4). Let us begin by assuming, for the moment only, that Pausanias is describing an actual journey.

Pausanias begins his description of Sikyon with mention of a ruined temple on the road from Corinth (2.5.5), before continuing with a lengthy genealogical, mythical, and historical account of the city from its foundation in the plain to its removal to the plateau (2.5.6-2.7.1). ${ }^{98}$ While still on the road from Corinth, but on the other side of the Asopos, he passes the tomb of the Athenian comic poet Eupolis, a grave, and a cenotaph (2.7.3-4). He then moves toward a gate close to "a dripping spring" and ascends to the plateau (2.7.4-5; Fig. 3:1). It is this gate and its accompanying spring that are normally taken to be the author's entrance to Sikyon proper, but the location of the spring has caused some debate. ${ }^{99}$ We do not know where the spring was, though in all probability it was located on the northeastern side of the plateau in one of the numerous gullies punctuating the limestone escarpment. In any case, after the spring is mentioned by Pausanias, there is a "topographic discontinuity" between his extra-urban route and the beginning of his description of the city. ${ }^{100}$

Pausanias continues his description of the city on the Hellenistic acropolis (2.7.5), which is assumed to be what the Sikyon Survey Project calls the Upper Plateau. ${ }^{101}$ It is the highest terrace on the Sikyonian plateau, and its slope serves as the cavea for the theater and the stadium. This assumption is based on the fact that Pausanias subsequently describes the theater and the Hellenistic monuments of the agora as being situated on the lower plateau; this lower plateau is then taken to be the Archaic and Classical acropolis of the city on the plain. ${ }^{102}$ Given the generally accepted rule of topographically determined sequences to Pausanias's city descriptions, this is probably accurate. ${ }^{103}$

On the Upper Plateau, Pausanias mentions temples of Tyche Akraia and the Dioskouroi (Fig. 3:2,3) with wooden cult statues (2.7.5). "Under" ( $(\pi 0$ ) the acropolis is the stage of the theater (Fig. 3:4), and "after" ( $\mu \varepsilon \tau \dot{\alpha}$ ) this is a temple to Dionysos (Fig. 3:5). On the right as one walks "from the

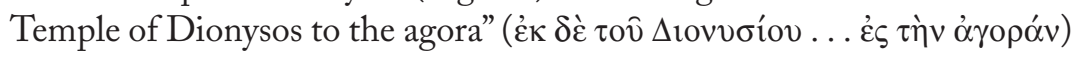
(2.7.6) is a temple to Artemis Limnaia (Fig. 3:6, 7). "Within the agora"

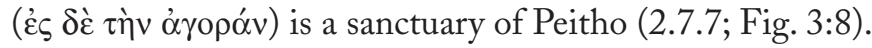

Up until this point, it seems that Pausanias has been describing a fairly linear trajectory: from the Upper Plateau, down past the theater, and toward the agora. With his description of the sanctuary of Peitho he

98. For the import of this genealogical digression, see Pirenne-Delforge 2008, pp. 54-64.

99. Bursian (1872, p. 27, n. 2) places the spring west of the modern village, whereas Frazer (1898, p. 48) puts it on the northeast side of the plateau. Curtius (1852, p. 488) thought it was near the church of Agia Triada on the northern plain beneath the plateau. There is a modern spring, the so-called

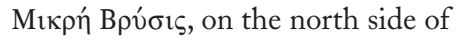
Vasiliko, and Earle (1889, p. 287) starts Pausanias's tour there. Griffin (1982, p. 15), though somewhat equivocal, implies agreement. Skalet (1928, p. 9, n. 36) thinks that the spring was lost by his time.

100. Hutton 2005, pp. 102-103, 134. This is typical of Pausanias's city descriptions. Only rarely does he continue his description past a gate and
Figure 3 (opposite). The literary topography of Pausanias's Sikyon, 2.5.5-2.11.2. Note that the two gymnasia (nos. 22, 27) may be a single feature. Shaded area indicates the agora. Drawing D. R. Stewart

into town: Athens (1.2.4-6), Pellene (7.27.1-4), Plataia (9.2.5), and Thebes (9.10.1).

101. Lolos, Gourley, and Stewart 2007, p. 272. See also Fig. 4, below.

102. Pausanias states in 2.5.6 that the Athena Temple was on the ancient acropolis. Skalet (1928, p. 25) sets the tone.

103. Hutton 2005, pp. 132-134. 


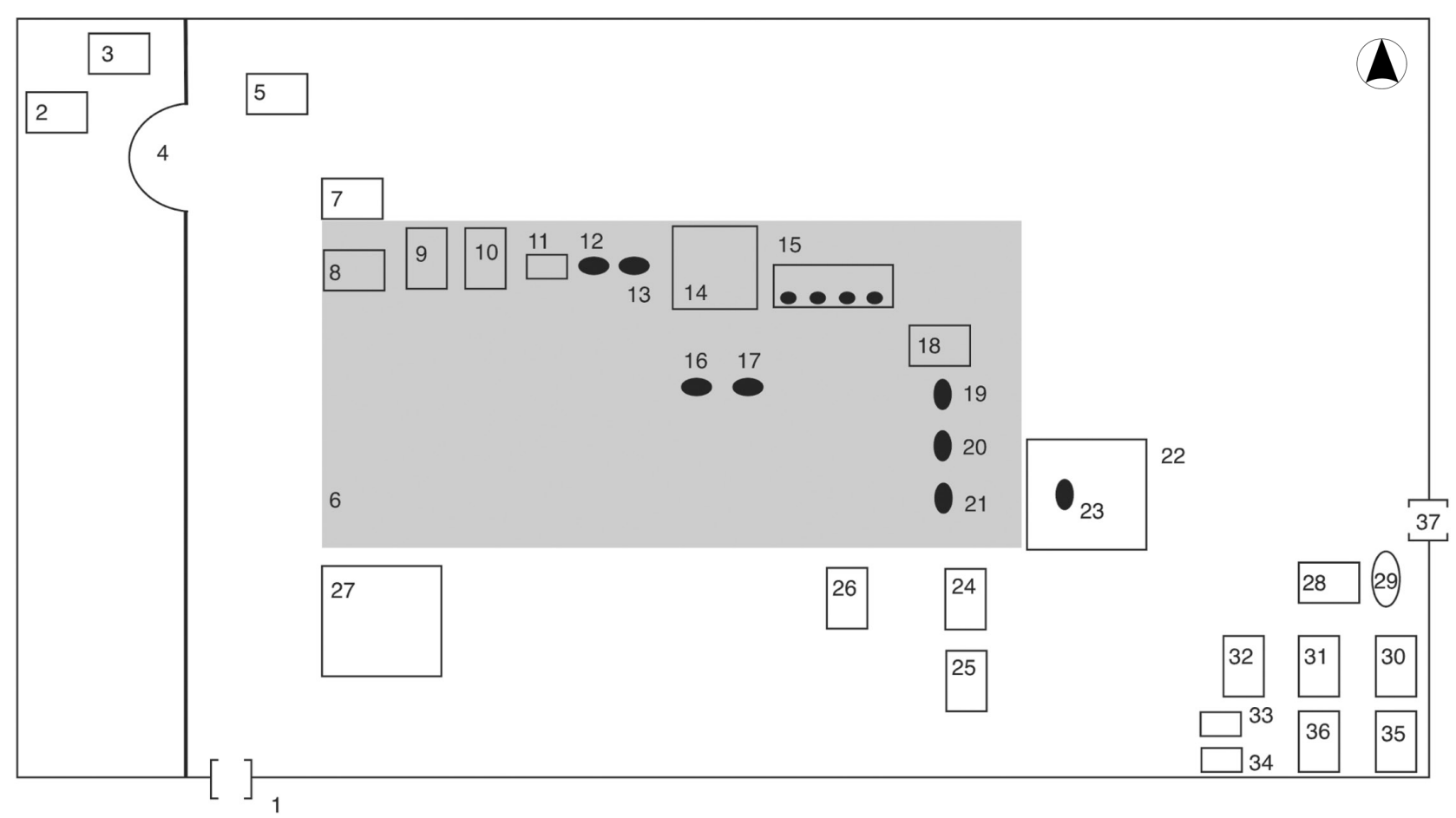

1. Dripping spring

2. Temple of Tyche Akraia

3. Temple of Dioskouroi

4. Theater

5. Temple of Dionysos

6. Agora

7. Temple of Artemis Limnaia

8. Sanctuary of Peitho

9. Imperial cult

10. Heroon of Aratos

11. Altar to Isthmian Poseidon

12. Statue of Zeus Meilichios

13. Statue of Artemis Patroa
14. Bouleuterion

15. Kleisthenic stoa

16. Bronze Zeus

17. Gilded Artemis

18. Sanctuary of Apollo Lykeios

19. Bronze Daughters of Proitos

20. Bronze Herakles

21. Hermes of the Agora

22. Gymnasion/Sanctuary of Herakles

23. Stone Herakles

24. Asklepieion

25. Sanctuary of Aphrodite

26. Sanctuary of Artemis Pheraea
27. Gymnasion of Kleinias

28. Temple of Athena

29. Grave of Epopeus

30. Sanctuary for the "Averters of Evil"

31. Sanctuary of Artemis and Apollo

32. Sanctuary of Hera

33. Altar to Pan

34. Altar to Helios

35. Temple of Apollo Karneios

36. Temple of Hera Prodromia

37. Sacred Gate

states he is now in the agora. It is generally assumed that he then continues walking in the same direction (basically easterly) when he describes the other monuments of the agora. ${ }^{104}$ First, however, comes a digression on how the worship of Peitho came to be established at Sikyon (2.7.7-9). When his topographic description picks up again with the temenos to the Roman emperors (located in the tyrant Kleon's old house: 2.8.1; Fig. 3:9), we have no real way of knowing which way he is facing, or in what direction

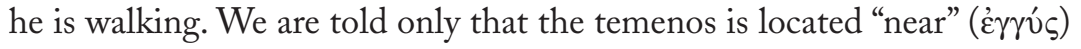
the sanctuary of Peitho.

Pausanias then moves from the temenos to the heroon of Aratos (2.9.4, 6; Fig. 3:10), "after" ( $\mu \varepsilon \tau \alpha$ ') which he notes an altar to Isthmian Poseidon and two statues (2.9.6; Fig. 3:11-13). "Here too" ( $\dot{\varepsilon} \tau \alpha \alpha \hat{v} \theta \alpha)$ is the Bouleuterion (Fig. 3:14) and a Kleisthenic stoa (Fig. 3:15). "Under the open sky" ('ُv $\tau \hat{\text { v }} \mathrm{v} \pi \alpha i \theta \rho \omega)$ is a bronze Zeus and next to it a gilded Artemis (2.9.6-7; Fig. 3:16, 17). "Neighboring" ( $\pi \lambda \eta \sigma i ́ o v)$ these statues is a sanctuary of Apollo Lykeios (2.9.7; Fig. 3:18). At this point, the reconstructed route

104. Skalet 1928, p. 17; Griffin 1982, pp. 17-18. 
in Figure 3 turns south, largely because I believe Pausanias's shift from the stoa to the statues and on to the Apollo Lykeios sanctuary represents a shift in orientation, but also because I have stood in the agora myself and considered the dimensions of what he is describing. Walls of insulae are visible in the parch marks in the grass, and seem to agree with the size and orientation of insulae recovered through geophysical prospection. ${ }^{105} \mathrm{My}$ own autopsia, with all its concomitant frictions, is here laid bare.

Pausanias's description of the agora concludes with a few brief lines on three different statues (2.9.8; see Fig. 3:19-21). Again we encounter a "topographical discontinuity," 106 and, as Griffin states, "his route becomes rather obscure" 107 as his description jumps to a gymnasion (Fig. 3:22) "not

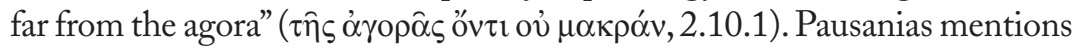
that it contained a Herakles by Skopas (Fig. 3:23), digresses to a description

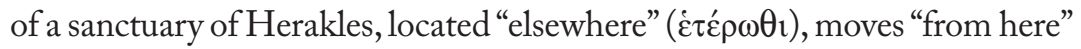
( $\dot{\varepsilon} v \varepsilon \hat{v} \theta \varepsilon v, 2.10 .2)$ to the sanctuaries of Asklepios and Aphrodite (Fig. 3:24, 25), passes a sanctuary of Artemis (Fig. 3:26), and then proceeds on to the Gymnasion of Kleinias (2.10.1-7; Fig. 3:27). It is not clear whether the move from the gymnasion to the Herakles sanctuary is part of his route, or simply a digression on the subject of statues of Herakles. It is also unclear from which point Pausanias then returns to his route- at the gymnasion, back at the agora, or from the sanctuary of Herakles. Determining his route is further complicated by the fact that the two gymnasia may in fact be one and the same. ${ }^{108}$ There is an extant Hellenistic gymnasion in the agora that could have been built by Kleinias, the father of Aratos. ${ }^{109}$

As William Hutton pointed out to me, there are at least four types of topographic discontinuity inherent to Pausanias's text, some of which have to do with the way Pausanias composes his text, and some of which have to do with the ways we interpret that text:

1) places where there is no stated or implied spatial relationship (for example, in his shift from the gate by the "dripping spring" to the acropolis [2.7.4-5]);

2) places where an indeterminate or vague spatial relationship is stated (as in the relationship between the agora and gymnasia, above);

3) places where no spatial relationship is stated, but we might assume one (as is perhaps the case with the Herakles monuments [2.10.1]);

4) places where a spatial relationship is stated that does not exist in reality (as in the example of the Temple of Aphaia on Aigina, which Pausanias wrongly describes as being "on the way" from the city to the shrine of Panhellenian Zeus [2.30.3]). ${ }^{110} \mathrm{I}$ have not been able to identify this sort of discontinuity at Sikyon.

Part of the problem for scholars comes not in identifying topographic discontinuities, but in categorizing them. This problem is further compounded for places such as Sikyon by our relatively ephemeral understanding of the archaeology or the 2nd-century A.D. urban form. In other words, it is difficult to understand the composition of aspects of the text
105. Gourley, Lolos, and Sarris 2009. See also the 2008 geophysics report on the Sikyon Survey Project's website: http://extras.ha.uth.gr/sikyon/ en/season2008e.asp.

106. This discontinuity is of a different type than that following the description of the gate by the "dripping spring." There, it appears that no topographic connection between the acropolis and the gate is implied. Here, Pausanias makes an explicit topographic connection. I owe this insight to William Hutton (pers. comm.).

107. Griffin 1982, p. 18; see also Skalet 1928, pp. 10, 22-25.

108. Leake (1830, pp. 361-363), Curtius (1852, p. 495), and Bursian (1872, p. 30) identify two gymnasia. Orlandos (1935) considered the possibility that they were the same feature.

109. Orlandos 1934, 1935; Delorme 1960, pp. 99-102.

110. On the history of scholarship on this sanctuary, see Watson 2011, pp. 80-87. The discovery of the "Great Aphaia Inscription" ( $I G$ IV.1 1580) in 1901 subsequently exposed Pausanias's topographic discontinuity. 
without understanding the landscapes Pausanias is responding to, yet it is hard to frame that understanding in a way that does not ultimately become circular.

After the gymnasia (or gymnasion), Pausanias then describes the Archaic acropolis and its temples, arguably the religious center of the ancient city. He begins this description by "turning away" ( $\dot{\alpha} \pi \circ \tau \rho \alpha \pi \varepsilon i \sigma \iota v)$ from the Hellenistic gymnasion toward the Sacred Gate (Fig. 3:37), which implies another topographic jump, though this time one that is roughly oriented if indistinct. The full passage describing this chain of monuments (2.11.1) reads as follows:

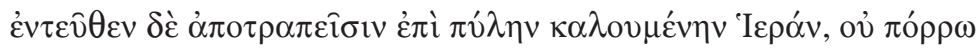

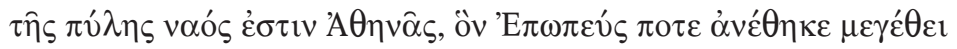

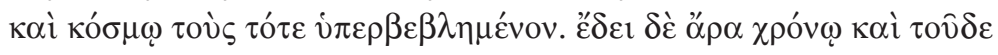

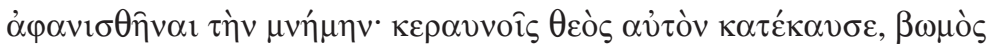

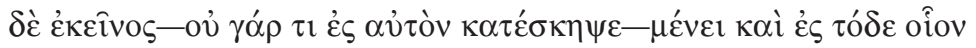

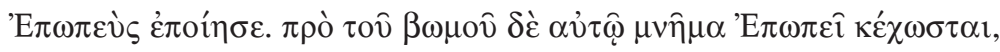

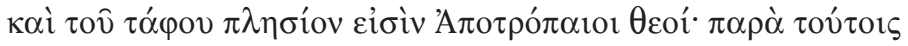

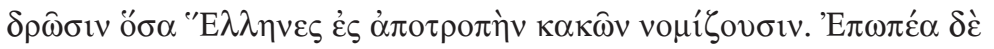

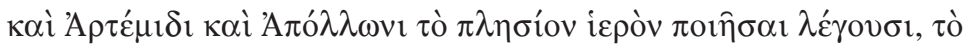

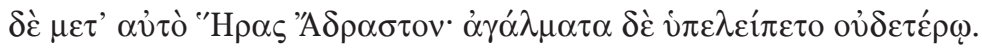

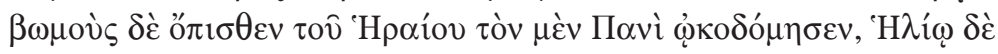
$\lambda i ́ \theta$ оง $\lambda \varepsilon$ коиิ.

The gate referred to by Pausanias is currently believed to be located somewhere close to the line of the modern road from coastal Kiato to the village of Vasiliko. ${ }^{111}$ It is here that the Temple of Athena (Fig. 3:28) once stood, though in Pausanias's day only the altar survived and the temple's memory

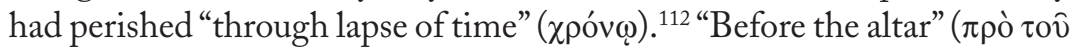
$\beta \omega \mu \mathrm{v})$ is the grave of Epopeus (Fig. 3:29), and "near" ( $\pi \lambda \eta \sigma i o v)$ that a sanc-

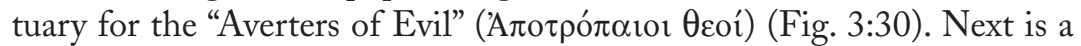
"neighboring sanctuary" ( "after it" ( $\mu \varepsilon \tau$ ' $\alpha$ $\tau o ́)$ one of Hera (Fig. 3:31, 32), neither of which has surviving cult images, suggesting that the cults are no longer active. "Behind" ("ó $₫ \sigma \theta \varepsilon v$ ) the Hera sanctuary are altars to Pan and Helios (Fig. 3:33, 34).

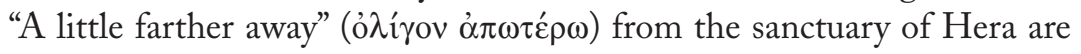
the temples of Apollo Karneios and Hera Prodromia (2.11.2; Fig. 3:35, 36). Pausanias then descends from the plateau toward the plain.

Figure 3 shows one possible literary topography that can be produced from a close reading of the text-but even this creates an impression of spatial certainty that is not evident in Pausanias's account. Griffin states that there is little archaeological evidence to help determine Pausanias's route, ${ }^{113}$ but that implies that our original assumption - that Pausanias was writing about one route-is accurate, and that further archaeological discoveries will illuminate what is obscure about Pausanias's description. Pausanias writes with indistinct prepositional phrases that place monuments "near," "after," "before," or "beyond,"114 and he supplies discourses on cult and myth in lieu of details on the location and orientation of the monuments he visits. Those monuments he does describe are done so with a lack of 


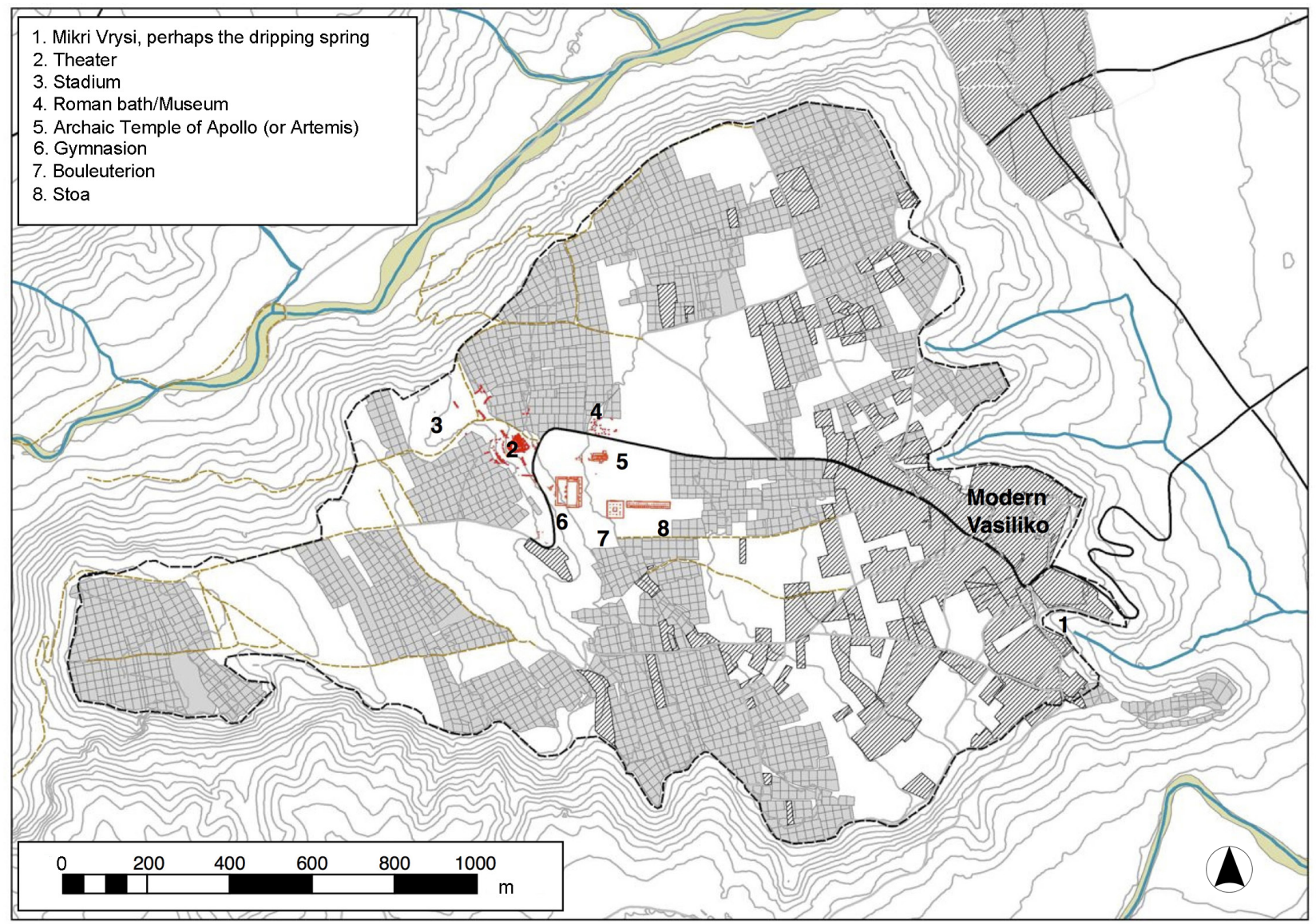

fixity; they are nebulous physical spaces whose import lies in their cultural and religious associations, not their walls.

The physical topography of the region and the surviving archaeological remains, as documented by the Sikyon Survey Project (Fig. 4), highlight this issue: the literary topography and the physical topography have points of congruence, for instance in the theater, the Bouleuterion, and perhaps aspects of the recovered gymnasion, but for the most part they do not align. From an archaeological point of view, it appears that the stadium is missing from the text, as is the sanctuary to the nymphs next to the extant gymnasion, and the two known Roman baths. Also, although as many as seven gates to the city have been posited, ${ }^{115}$ all but two are missing from the text, as are the streets, avenues, houses, workshops, and inhabitants of Sikyon. Even the agora itself, the area of the city most clearly described by Pausanias, and the area that has received the most attention from archaeologists, is the subject of conflicting literary and archaeological accounts. The surviving stoa, of Hellenistic date, is too late to be the stoa of Kleisthenes, and the identification of the Archaic temple is far from secure. ${ }^{116}$ These disjunctions cannot be resolved by further excavation.

Part of the problem that faces us is the range of assumptions, both literary and topographical, that have gone into the construction of this visual representation of the literary topography. I have assumed that there is meaning in Pausanias's prepositions, that they represent orientation
Figure 4. The contemporary physical topography of Sikyon, with known ancient monuments. Drawing Y. A. Lolos, B. Gourley, and D. R. Stewart

115. Lolos 2011, p. 208.

116. For the stoa, see Philadelpheus 1926, p. 49; Orlandos 1954, pp. 221222. On the identification of the Archaic temple, see n. 117, below. 
and movement. I have assumed a sequential topographic description, largely based on geographic relationships, and not a selective schematic description of relative positions (though I would argue that either stance supports my broader point). Perhaps most importantly, I have been unable to completely set aside my own experience of the Sikyonian plateau: the physical topography as I know it has colored my understanding of Pausanias's description.

While Pausanias is undoubtedly writing about places that he saw firsthand, there is no necessary congruence between his descriptions and the topographic layout of the physical landscape. It is important to stress, however, that it is not simply a case of the archaeological evidence belying Pausanias's description - my point is not that one mode of description is more accurate than the other, nor that the archaeological remains can "correct" the text (or vice versa). Rather, I suggest that the archaeological account and the text are describing different landscapes. Nevertheless, classical archaeologists have long used the points of agreement, the "reality" of the material on the ground, in a reciprocal manner with Pausanias's text: where Pausanias seems to agree with their discoveries, the authority of the archaeologist is supported, and the more the supposed reality of Pausanias's descriptions is demonstrated archaeologically, the more authoritative Pausanias becomes.

There are certainly areas of overlap, where the literary topography approaches the physical (or the inverse), but there is no necessary structure of similarity between Pausanias's text and the material remains. Those buildings listed above that are "missing" from Pausanias's text are not actually missing; rather they are not part of the literary landscape that Pausanias constructed. The text should not be a proxy for what is archaeologically absent: Pausanias and archaeology are doing different things.

Researchers have tried to account for these differences in a variety of ways, but have done so in an attempt to prolong the desired "structure of similarity" between the text and the material remains. As such, these differences have been interpreted as the result of problems in archaeological recovery or contemporary topographical understandings, ${ }^{117}$ or as the result of errors in recording made by Pausanias. ${ }^{118}$ In other words, approaches have continued to use notions of autopsy in order to reconstruct the "accurate" landscape of Sikyon by either proving, amending, or superseding Pausanias. We are still embroiled in the same quest for authority as every other author.

117. For example, on the identification of the Archaic temple in the agora, see Skalet 1928, pp. 16-17; Griffin 1982, pp. 14, 16-17. Orlandos (1936, p. 94) identified the temple as that of Artemis, without providing any justification. Roux (1958, pp. 143-144) dismissed Orlandos's identification and argued instead for Apollo, based on his reading of Pausanias 2.7.6-7 and the subsequent transformation of the temple into an Early Christian basilica. Krystalli-Votsi and Østby (2010, p. 56) support Roux's identification, based on work they carried out in the late 1980s. Their argument rests on the recovery of a partially preserved circular slab with a deep hole near its edge that they interpret as a base for a monumental tripod, which would be more suited to the worship of Apollo than Artemis. Interestingly, in its Hellenistic phase the temple appeared "like a small stoa" and its cultic associations were "intentionally toned down" by placing the altar near the northern flank of the structure (Krystalli-Votsi and Østby 2010, p. 57). While there is an Archaic predecessor to the Hellenistic temple, it was substantially remodeled/rebuilt around the close of the 4th century в.c. (Krystalli-Votsi and Østby 2010, pp. 55-60). Not considered by any author is that this temple may have been dedicated to neither Artemis nor Apollo. Pausanias mentions two temples; therefore, this must be one of them.

118. Skalet 1928, pp. 4-5, 16-17; Lolos, Gourley, and Stewart 2007, pp. 289-290; Lolos 2011, pp. 409-414. 
Surprisingly, there have been very few attempts to reconstruct Pausanias's route through Sikyon, perhaps largely because it has been seen as unproblematic. ${ }^{119}$ However, Pausanias's process of constructing his description sheds important light on his overall project - the way in which he translates his meanderings into textual description is a central pillar in how he constructs his sense of memory and time. The writing is the first act of remembrance, but it is far from the last. The failure to take this into account has led to the perpetuation of the disconnect between Sikyon's physical and literary topographies. Attempts to read the textual descriptions into the physical remains only serves to perpetuate the myth that you can peel back the layers of text and find within them the "real" place.

Identifying the "real" place, however, is not a straightforward procedure. There are discontinuities between ancient authors that reflect different emphases on the most essential or defining characteristics of the city; ancient sources reveal five differently named Sikyons ${ }^{120}$ representing different aspects of memory and identity:

1. Aigialeia (Paus. 2.5.6; Strabo 8.382). This name is taken from Aigialeus, founder and first king of Sikyon. Pausanias says he is an autochthonous king predating the Dorian invasion. Hesychios applies the name Aigialeis to the Ionians who went with Agamemnon to Troy, and in some sources the name is applied to the entire coastal strip of Achaia (e.g., Euphorion fr. 83 Lightfoot [ $\Sigma$ b Il. 2.498c, i, p. 292, line 96 Erbse]).

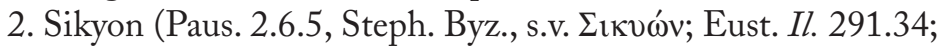

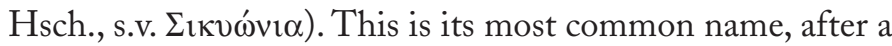
mythical king, or perhaps a cucumber.

3. Mekone (Strabo 8.382; Steph. Byz., s.v. Lıкvต́v; Eust. Il. 291.22). This name derives from Demeter's discovery of the poppy $(\mu \eta \dot{\kappa} \kappa \omega)$ at the site. A poppy was one of the attributes of the cult statue of Aphrodite (Paus. 2.10.5) at the city, and Hesiod (Theog. 535-544) says that it was at Mekone that Prometheus tricked the gods into accepting the inferior parts of sacrificial victims. This name is unmentioned by Pausanias.

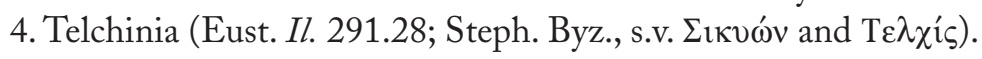
The name is supposedly related to the Telchines, the legendary inventors of metalwork, though they themselves are normally placed in Crete, Rhodes, or Cyprus; in any case, it is a suitable name for a city known as an artistic center. The name Telchis appears in Pausanias's king list, though he does not mention the name Telchinia.

5. Demetrias (Diod. Sic. 20.102.3; Plut. Demetr. 25.3). This is the name of the "new" city founded on the plateau by Demetrios Poliorcetes. This name did not survive for any significant length of time. A fragmentary inscription recovered from the Athenian Agora suggests that the city name had reverted from Demetrias back to Sikyon within a few months. ${ }^{121}$

These five Sikyons represent five different textual topographies of the city, each seeking to explain the physical place in terms of its history. Yet none of these traditions represent the totality of the physical city, but
119. Robert (1909, p. 118) chose Sikyon as his "classic" example of Pausanias's acropolis-type of topographical description. Piérart (2001, p. 213) sees the rest of book 2 (as in the Argolid) as being more complicated than the "northern" sections.

120. These names are listed by Griffin (1982, pp. 4-5).

121. Agora I 2636: Agora XVI, pp. 182-186, no. 115; SEG XLI 50; Camp 2003, pp. 273-275. For a more detailed discussion, see Lolos 2011, pp. $72-73$. 
122. Elsner 2010a, p. 160.

123. See, e.g., Paus. 2.9.7 on the Temple of Apollo Lykeios (which may be the excavated temple visible at the contemporary archaeological site), 2.7.6 on the ruined Artemis Limnaia (of the Lake), and 2.11.1 on the state of the Temple of Athena.

124. It is perhaps telling that in Pausanias's account, the heroon of Aratos is situated next to a temenos of the Roman emperors, which was itself located in the old house of the tyrant Kleon (2.8.1-2). Is Pausanias equating his contemporary political situation with Hellenistic tyranny? Elsner (1995, p. 143) suggested that this was a glimpse into Pausanias's views on Roman rule, though this is disputed by Steinhart (2002). PirenneDelforge (2008, p. 60) sees it in more complex terms, with the heroized Aratos and the tyrant Kleon spatially juxtaposed, as determined by Pausanias's view of dike, that is, with the just rewarded and the unjust supplanted. This reading makes Pausanias's attitude toward Rome much more neutral. On the broader issue of the complexity of Pausanias's attitudes toward Roman rule, see Hutton 2008; Pirenne-Delforge 2008, pp. 142-173.

125. My thanks to William Hutton for highlighting this point (pers. comm.). rather refer to different aspects of it. One can understand the city in terms of its autochthonous monarchy, its relationship to the establishment of cult practice, its place within the political history of the diadochoi, its agricultural produce, or through some combination of the above. But to map only one of these literary topographies onto the physical remains is akin to admiring the Mona Lisa only for Leonardo's brushstrokes, while ignoring technique, composition, and choice of colors. There is, in Pausanian scholarship, a tension between excerption and completeness, between focusing on the selections of the author or the totality of the work, that remains unresolved. Elsner has referred to this as the "impasse of completeness versus selectivity" in describing the 19th-century reception of the periegetes. ${ }^{122}$

Each of these toponymic traditions is tied to different conceptions of memory and time. They represent the convergence of myth, history, and ritual. Contained within the textual description of Pausanias's Sikyon is a fascinating construction of memory and time that reflects his concerns as a member of the Greek elite under Roman rule, and the anxieties of contemporary Sikyonians living in a declining city. The Sikyonians' own stories about the founding of their cults and their link to a pre-Dorian past reflect their anxiety of living in a ruined city moved from its original site (Paus. 2.5.6).

Pausanias tells us of this ruined city, suggests that there is some dislocation between the memory of the inhabitants and their past, and implies that the inhabitants themselves are losing their connection to their past through their loss of cult places. ${ }^{123}$ Indeed, his account of Sikyon is framed by descriptions of ruined temples- that of Apollo on the road from Corinth (2.5.2), and those of Hera Prodromia and Apollo Karneios (2.11.2) by the Sacred Gate. The reifying permanence of Pausanias's ritual time is being lost to the exigencies of contemporary Roman Greece, which is reflected in the parlous state of many of the oldest cults of the polis. ${ }^{124}$ Indeed, Pausanias's use of the present tense in reference to the "Averters of Evil" ('A $\pi$ o $\theta \varepsilon o$, 2.11.1) might imply that this is the only cult still functioning in this area of the acropolis in his day, juxtaposed as it is with the apparent abandonment of the other shrines in the area. Throughout his description of the city is an undertone of decline. Pausanias describes the gymnasion of Kleinias as the place where "they still train the ephebes" (2.10.7), as if he is surprised to find it being used for this purpose. ${ }^{125} \mathrm{Within}$ the city are many ruined temples and cults: that of Artemis Limnaia, Peitho, the sanctuary of Apollo Lykeios, the Temple of Athena, the sanctuaries of Artemis and Apollo and of Hera, the altars to Pan and Helios, and the temples to Apollo Karneios and Hera Prodromia.

Those temples and cults, on the cusp of abandonment in Pausanias's day, are now lost to us. More than the loss of the physical monuments, however, Pausanias regrets the loss of the cult practices, of the traditions that explained the existence of those cults in those places. The people we do encounter within his text are unsure of their own history, or seem on the verge of losing it. Sanctuaries have fallen into disrepair; Hellenistic glories are juxtaposed with contemporary ruin and religious ambivalence. Archaeology may recover the foundations and detritus of past cult practice, but it cannot recover the memorialization of loss; for that we must turn to Pausanias's text. That is the benefit of literary topographies, 
and therein lies the danger in their unmediated use as proxies for material remains.

The Sikyon of Pausanias represents only one facet of that city, and it is far from definitive. Within his description he is emphasizing those characteristics that agree most with his own vision of what that landscape encapsulates. Pausanias's Sikyon is a demoralized, dilapidated city on the brink of sliding into obscurity. His lengthy mythological history (especially as compared with that of Corinth) serves to emphasize how much has changed within the polis-from proud beginnings to ignominy. To use his description to understand the surviving physical remains in the landscape is, to some degree, to accept his vision of the city. To impose Pausanias's vision on the archaeological remains, as has been the case at so many sites, not only does a disservice to the story the remains themselves can tell, it also does a disservice to Pausanias's text. The value of Pausanias for archaeology lies not only in allowing us to access aspects of lost physical landscapes, but also in allowing archaeology to access other culturally constructed landscapes that existed alongside the physical.

\section{CONCLUSION}

It is tempting to mistake the descriptive power of textual analogy within archaeology for explanatory certainty, and this has been one of the fundamental limitations in the relationship between Pausanias and classical archaeologists. His descriptions have been seen as explanations; in some cases they were thought to explain recovered remains, while in other cases they were taken as explanations for gaps in the archaeological record. As stated earlier, however, analogy is a means of approximating the new through reference to the old, with "approximation" implying imprecision, estimation, and approaching but not equaling.

The traditional hunt for the archaeological embodiment of textual topographic descriptions, the use of text as unmediated analogue, and the search for the "true picture of that larger landscape" ${ }^{126}$ within topographical authors mask an important assumption: that anyone who had accompanied the authors in those physical landscapes would have agreed with their descriptions, and would have recognized those descriptions from their own experience. Pausanias's allusions, his construction of time and memory within his text, and his selectivity argue against this assumption. He is creating a memorialized mythic and historic landscape, and not merely cataloguing the physical landscape.

Pausanias's text is a complicated construction. Within its descriptions the landscape is constructed as an embodiment of mytho-historic traditions, which is itself constructed through selection. From Pausanias's account we gain a detailed view of what he found interesting within a narrow corridor. Some have seen this as problematic; what Snodgrass called Pausanias's "relentless linearity" and Hutton referred to as his "tunnel vision" makes him a difficult source for anyone interested in a "true picture of that larger landscape." ${ }^{27}$ This quality is part of what makes his text so difficult to map onto material remains, yet so beguiling in the attempt.

126. Hutton 2005, p. 120.

127. Snodgrass 1987, p. 84; Hutton 2005, pp. 118-122. 


\section{REFERENCES}

Agora $=$ The Athenian Agora: Results of Excavations Conducted by the American School of Classical Studies at Athens, Princeton

$\mathrm{III}=\mathrm{R}$. E. Wycherley, Literary and Epigraphical Testimonia, 1957.

$\mathrm{XIV}=\mathrm{H}$. A. Thompson and R. E. Wycherley, The Agora of Athens: The History, Shape, and Uses of an Ancient City Center, 1972.

XVI = A. G. Woodhead, Inscriptions: The Decrees, 1997.

Akujärvi, J. 2005. Researcher, Traveller, Narrator: Studies in Pausanias' Periegesis (Studia Graeca et Latina Lundensia 12), Stockholm.

Alcock, S. E. 1996. "Landscapes of Memory and the Authority of Pausanias," in Bingen 1996, pp. 241-267.

_. 2001. "The Peculiar Book IV and the Problem of the Messenian Past," in Alcock, Cherry, and Elsner 2001, pp. 142-153.

Alcock, S. E., J. F. Cherry, and J. Elsner, eds. 2001. Pausanias: Travel and Memory in Roman Greece, Oxford.

Allison, P. M. 1997. "Artefact Distribution and Spatial Function in Pompeian Houses," in The Roman Family in Italy: Status, Sentiment, Space, ed. B. Rawson and P. Weaver, Oxford, pp. 321-354.

- 2001. "Using the Material and Written Sources: Turn of the Millennium Approaches to Roman Domestic Space," AJA 105, pp. 181208.

- 2004. Pompeian Households: An Analysis of Material Culture (Cotsen Institute of Archaeology Monograph 42), Los Angeles.

Appadurai, A., ed. 1986. The Social Life of Things: Commodities in Cultural Perspective, Cambridge.

Arafat, K. W. 1996. Pausanias' Greece: Ancient Artists and Roman Rulers, Cambridge.

Ascher, R. 1961. "Analogy in Archaeological Interpretation," Southwestern Journal of Anthropology 17, pp. 317-325.

Baird, J. A. 2006. "Housing and Households at Dura-Europus: A Study in Identity on Rome's Eastern Frontier" (diss. Univ. of Leicester).
. 2007. "The Bizarre Bazaar:

Early Excavations in the Roman East and Problems of Nomenclature," in TRAC'06: Theoretical

Roman Archaeology Conference Proceedings, ed. B. Croxford, N. Ray, R. Roth, and N. White, Oxford, pp. 34-42.

Bingen, J., ed. 1996. Pausanias historien: Huit exposés suivis de discussions, Vandoeuvres-Genève, 15-19 août 1994 (EntrHardt 41), Geneva.

Bodin, J. [1566] 1945. Method for the Easy Comprehension of History (Methodus ad faciliem historiarium cognitionem), trans. B. Reynolds, New York.

Bowie, E. L. 1996. "Past and Present in Pausanias," in Bingen 1996, pp. 207-230.

- 2001. "Inspiration and Aspiration: Date, Genre, and Readership," in Alcock, Cherry, and Elsner 2001, pp. 21-32.

Bultrighini, U. 2001. “'Errori' in Pausania: 3.8.10," in Knoepfler and Piérat 2001, pp. 239-260.

Bursian, C. 1872. Geographie von Griechenland 2, Leipzig.

Calligas, E., and J. Whitley, eds. 2005. On Site: British Archaeologists in Greece, Athens.

Camp, J. McK. 2003. "Excavations in the Athenian Agora, 1998-2001," Hesperia 72, pp. 241-280.

- 2009. "The Archaeology of the Agora: A Summary," in The Athenian Agora: New Perspectives on an Ancient Site, ed. J. McK. Camp and C. A. Mauzy, Mainz, pp. 11-38.

Casson, L. 1994. Travel in the Ancient World, 2nd ed., Baltimore.

Chapman, J. 1999. "Archaeological Proxy-Data for Demographic Reconstructions: Facts, Factoids, or Fiction?" in Reconstructing Past Population Trends in Mediterranean Europe (3000 B.C.-A.D. 1800) (The Archaeology of Mediterranean Landscapes 1), ed. J. Bintliff and K. Sbonias, Oxford, pp. 65-76.

Clarke, M., and N. Penny, eds. 1982. The Arrogant Connoisseur: Richard Payne Knight, 1751-1824: Essays on Richard Payne Knight together with a Catalogue of Works Exhibited at the Whitworth Art Gallery, 1982, Manchester.

Corinth = Corinth: Results of Excavations Conducted by the American School of

Classical Studies at Athens, Princeton VII. 3 = G. R. Edwards, Corinthian Hellenistic Pottery, 1975.

$\mathrm{XX}=\mathrm{C} . \mathrm{K}$. Williams II and N. Bookidis, eds., Corinth, the Centenary: 1896-1996, 2003.

Curtius, E. 1852. Peloponnesos: Eine historisch-geographische Beschreibung der Halbinsel 2, Gotha.

Delorme, J. 1960. Gymnasion: Étude sur les monuments consacrés à l'éducation en Grèce (des origines à l'Empire romain) (BÉFAR 196), Paris.

Diller, A. 1955. "The Authors Named Pausanias,” TAPA 86, pp. 268-279.

-1956. "Pausanias in the Middle Ages,” TAPA 87, pp. 84-97.

_. 1957. "The Manuscripts of Pausanias," TAPA 88, pp. 169-188.

Dodwell, E. 1819. A Classical and Topographical Tour through Greece during the Years 1801, 1805, and 1806, vol. 2, London.

Dueck, D. 2000. Strabo of Amasia: A Greek Man of Letters in Augustan Rome, London.

Dyson, S. L. 1988. "The Relevance for Romanists of Recent Approaches to Archaeology in Greece," JRA 1, pp. 143-146.

2006. In Pursuit of Ancient Pasts: A History of Classical Archaeology in the Nineteenth and Twentieth Centuries, New Haven.

Earle, M. L. 1889. "Excavations by the American School at the Theatre of Sikyon II: Supplementary Report of the Excavations," The American Journal of Archaeology and of the History of the Fine Arts 5, pp. 286292.

Elsner, J. 1992. "Pausanias: A Greek Pilgrim in the Roman World," PastPres 135, pp. 3-29.

— 1994. "From the Pyramids to Pausanias and Piglet: Monuments, Travel, and Writing," in Art and Text in Ancient Greek Culture, ed. S. Goldhill and R. Osborne, Cambridge, pp. 224-254. 


. 1995. Art and the Roman
Viewer: The Transformation of Art
from the Pagan World to Christianity,
Cambridge.
. 2001. "Structuring 'Greece':
Pausanias' Periegesis as a Literary
Construct," in Alcock, Cherry, and
Elsner 2001, pp. 3-20.
. 2010a. "Introduction," Classical
Receptions Journal 2, pp. 157-173.
. 2010b. "Picturesque and Sub-
lime: Impacts of Pausanias in Late-
Eighteenth- and Early-Nineteenth-
Century Britain," Classical Receptions
Journal 2, pp. 219-253.

Emerson, M. 2007. Greek Sanctuaries: An Introduction, London.

Engels, J. 1999. Augusteische Oikumenegeographie und Universalhistorie im Werk Strabons von Amaseia (Geographica historica 12), Stuttgart.

Fossum, A. 1905. "The Theatre at Sikyon," AJA 9, pp. 263-276.

Fotiadis, M. 1995. "Modernity and the Past-Still-Present: Politics of Time in the Birth of Regional Archaeological Projects in Greece," AJA 99, pp. 59-78.

Foucault, M. [1972] 2002. The Archaeology of Knowledge (Routledge Classics), trans. A. M. Sheridan Smith, London.

Frazer, J. G. 1898. Pausanias's Description of Greece 3, London.

Frenzel, B., A. Pons, and B. Gläser, eds. 1991. Evaluation of Climate Proxy Data in Relation to the European Holocene (Paläoklimaforschung 6; ESF Project "European Palaeoclimate and Man,” Special Issue 1), Stuttgart.

Gaifman, M. 2010. "Pausanias and Modern Perceptions of Primordial Greeks," Classical Receptions Journal 2, pp. 254-286.

Gebhard, E. R., and M. W. Dickie. 2003. "The View from the Isthmus, ca. 200 to 44 в.c.," in Corinth XX, pp. 261-278.

Gehrke, H.-J. 1986. Jenseits von Athen und Sparta: Das dritte Griechenland und seine Staatenwelt, Munich.

Gosden, C., and Y. Marshall. 1999. "The Cultural Biography of Objects," WorldArch 31, pp. 169-178.

Gourley, B., Y. A. Lolos, and A. Sarris. 2009. "Application of Integrated
Geophysical Prospection Techniques for Mapping Ancient Sikyon, Greece," in Advances on Remote Sensing for Archaeology and Cultural Heritage Management, ed. R. Lasaponara and N. Masini, Rome, pp. 169-173.

Greene, K. 2005. "Roman Pottery: Models, Proxies, and Economic Interpretation," JRA 18, pp. 34-56.

Griffin, A. 1982. Sikyon (Oxford Classical and Philosophical Monographs), Oxford.

Grosjean, M., I. Cartajena, M. A. Geyh, and L. Nuñez. 2003. "From Proxy Data to Paleoclimate Interpretation: The Mid-Holocene Paradox of the Atacama Desert, Northern Chile," Palaeogeography, Palaeoclimatology, Palaeoecology 194, pp. 247-258.

Guilmet, C. 2007. "The Survival of Pausanias' Text," in Following Pausanias: The Quest for Greek Antiquity, ed. M. Georgopoulou, C. Guilmet, Y. A. Pikoulas, K. S. Staikos, and G. Tolias, Athens, pp. 52-53.

Gurlitt, W. 1890. Über Pausanias: Untersuchungen, Graz.

Habicht, C. 1984. "Pausanias and the Evidence of Inscriptions," ClAnt 3, pp. $40-56$.

P. [1985] 1998. Pausanias' Guide to Ancient Greece (Sather Classical Lectures 50), repr. Berkeley.

Hamilakis, Y. 2007. The Nation and Its Ruins: Antiquity, Archaeology, and National Imagination in Greece (Classical Presences), Oxford.

Hamilakis, Y., and E. Yalouri. 1996. "Antiquities as Symbolic Capital in Modern Greek Society," Antiquity 70, pp. 117-129.

Harloe, K. 2010. "Pausanias as Historian in Winckelmann's History," Classical Receptions Journal 2, pp. 174-196.

Harrison, E. B. 1977a. “Alkamenes' Sculptures for the Hephaisteion, Part I: The Cult Statues," AJA 81, pp. 137-178. . 1977b. "Alkamenes' Sculptures for the Hephaisteion, Part III: Iconography and Style," AJA 81, pp. 411-426. - 1979. "The Architectural Sculptures of the So-Called Theseum," in Greece and Italy in the Classical World. Acta of the XI International Congress of Classical Archaeology, on Behalf of the International Association for Classical Archaeology, London, 3-9 September 1978, under the Sponsorship of the British Academy, ed. J. N. Coldstream and M. A. R. Colledge, London, p. 220 (abstract).

Hastaoglou-Martinidis, V. 1995. “City Form and National Identity: Urban Designs in Nineteenth-Century Greece," Journal of Modern Greek Studies 13, pp. 99-123.

Herzfeld, M. 2001. "Performing Comparisons: Ethnography, Globetrotting, and the Spaces of Social Knowledge," Journal of Anthropological Research 57, pp. 259-276.

Hodder, I. 1993. “The Narrative and Rhetoric of Material Culture Sequences," WorldArch 25, pp. 268282.

Howell, M., and W. Prevenier. 2001. From Reliable Sources: An Introduction to Historical Methods, Ithaca.

Hurwit, J. M. 1999. The Athenian Acropolis: History, Mythology, and Archaeology from the Neolithic Era to the Present, Cambridge.

Hutton, W. 2005. Describing Greece: Landscape and Literature in the Periegesis of Pausanias (Greek Culture in the Roman World), Cambridge.

- 2008. "The Disaster of Roman Rule: Pausanias 8.27.1," CQ 58, pp. 622-637.

Itkonen, E. 2005. Analogy as Structure and Process: Approaches in Linguistics, Cognitive Psychology, and Philosophy of Science (Human Cognitive Processing 14), Philadelphia.

Jacquemin, A. 2001. "Pausanias, le sanctuaire d'Olympie, et les archéologues," in Knoepfler and Piérat 2001, pp. 283-300.

Jantzen, U. 1986. Einhundert Jahre Athener Institut, 1874-1974 (Das Deutsche Archäologische Institut, Geschichte und Dokumente 10), Mainz.

Jones, C. P. 1986. Culture and Society in Lucian, Cambridge.

Jost, M. 2007. "Pausanias in Arkadia: An Example of Cultural Tourism," in Travel, Geography, and Culture in 
Ancient Greece, Egypt, and the Near East (Leicester Nottingham Studies in Ancient Society 10), ed. C. Adams and J. Roy, Oxford, pp. 104-122.

Juthe, A. 2005. "Argument by Analogy," Argumentation 19, pp. 1-27.

Knoepfler, D., and M. Piérat, eds. 2001. Éditer, traduire, commenter Pausanias en l'an 2000. Actes du colloque de Neuchâtel et de Fribourg (18-22 Septembre 1998) autour des deux éditions en cours de la Périégèse (Recueil de travaux publiés par la Faculté des lettres et sciences humaines 49), Geneva.

Koch, H. 1955. Studien zum Theseustempel in Athen (AbbLeip 47.2), Berlin.

Kourinou, E. 2000. $\Sigma \pi \alpha \dot{\alpha} \rho \tau \eta: \Sigma v \mu \beta o \lambda \eta ́$ $\sigma \tau \eta \mu \nu \eta \mu \varepsilon i \alpha \kappa \eta ́ ~ \tau о \pi о \gamma \rho \alpha \varphi i ́ \alpha \tau \eta \varsigma$, Athens.

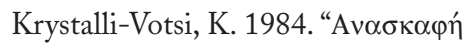

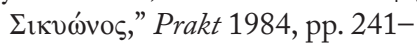
242.

Krystalli-Votsi, K., and E. Østby. 2010. "The Temples of Apollo at Sikyon," Bolletino di Archeologia On Line (Special Issue: XVII International Congress of Classical Archaeology: "Meetings between Cultures in the Ancient Mediterranean," Rome 2008), pp. 54-62; http://www .bollettinodiarcheologiaonline .beniculturali.it/bao_document/ poster/8_Krystalli_OSTBY.pdf.

Lafond, Y. 2001. "Lire Pausanias à l'époque des Antonins. Réflexions sur la place de la Périégèse dans l'histoire culturelle, religieuse, et sociale de la Grèce romaine," in Knoepfler and Piérat 2001, pp. 387406.

Leach, E. W. 1997. “Oecus on Ibycus: Investigating the Vocabulary of the Roman House," in Sequence and Space in Pompeii (Oxbow Monograph 77), ed. S. E. Bon and R. Jones, Oxford, pp. 50-72.

Leake, W. M. 1830. Travels in the Morea, with a Map and Plans 2, London.

Lolos, Y. A. 2005. "The Sanctuary of Titane and the City of Sikyon," BSA 100, pp. 275-298.

- 2011. Land of Sikyon: Archaeology and History of a Greek City-State (Hesperia Suppl. 39), Princeton.
Lolos, Y. A., B. Gourley, and D. R. Stewart. 2007. “The Sikyon Survey Project: A Blueprint for Urban Survey?" JMA 20, pp. 267-296.

Lord, L. E. 1947. A History of the American School of Classical Studies at Athens, 1882-1942: An Intercollegiate Project, Cambridge, Mass.

Loukaki, A. 2008. Living Ruins, Value Conflicts (Heritage, Culture, and Identity), Aldershot.

Luraghi, N. 2008. "Meeting Messenians in Pausanias' Greece," in Le Péloponnèse d'Épamindondas à Hadrien. Colloque de Tours, 6-7 octobre 2005 (Études 21), ed. C. Grandjean, Bordeaux, pp. 191-202.

MacCormack, S. 2010. "Pausanias and His Commentator Sir James George Frazer," Classical Receptions Journal 2, pp. 287-313.

Marasco, G. 1978. I viaggi nella Grecia antica (Bibliotheca Athena 22), Rome.

Marchand, S. L. 1996. Down from Olympus: Archaeology and Philhellenism in Germany, 1750-1970, Princeton.

Marincola, J. 2004. Authority and Tradition in Ancient Historiography, Cambridge.

Mau, A. 1904. Pompeii: Its Life and Art, trans. F. W. Kelsey, rev. ed., New York.

McCarthy Young, K., and G. Leinhardt. 1998. "Wildflowers, Sheep, and Democracy: The Role of Analogy in the Teaching and Learning of History," in Learning and Reasoning in History (Woburn Education Series, International Review of History Education 2), ed. J. F. Voss and M. Carretero, London, pp. 154196.

McMurtry, W. J. 1889. “Excavations by the American School at the Theatre of Sikyon I: General Report of the Excavations," AJA 5, pp. 267-286.

Meritt, L. S. 1984. History of the American School of Classical Studies at Athens, 1939-1980, Princeton.

Millett, M. 2000. "Dating, Quantifying, and Utilizing Pottery Assemblages from Surface Survey," in Extracting Meaning from Ploughsoil Assemblages (The Archaeology of Mediterranean Landscapes 5), ed. R. Francovich,
H. Patterson, and G. Barker, Oxford, pp. 53-59.

Millis, B. 2006. “'Miserable Huts' in Post-146 в.c. Corinth,” Hesperia 75, pp. 397-404.

Musti, D. 1996. "La struttura del discorso storico in Pausania," in Bingen 1996, pp. 9-43.

Musti, D., and M. Torelli, eds. 1991. Pausanias: Guida della Grecia 3: La Laconia (Scrittori greci e latini), Milan.

Nenna, M.-D., ed. 1996. L'espace grec: 150 ans de fouilles de l'École française d'Athènes, Paris.

Orlandos, A. C. 1934. "La fontaine de Sicyone," AJA 38, pp. 153-157.

_. 1935. “Аv Prakt 1935, pp. 73-83.

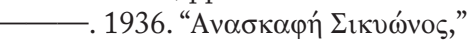
Prakt 1936, pp. 86-94.

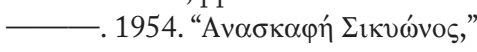
Prakt 1954, pp. 219-231.

Osanna, M. 1998. "Descrizione autoptica e rielaborazione 'a tavolino' in Pausania: Il caso di Aigeira," in Les Panthéons des cités: Des origines à la Périégèse de Pausanias. Actes du colloque organisé à l'Université de Liège du 15 au 17 mai 1997, $2^{e}$ partie (Kernos Suppl. 8), ed. V. PirenneDelforge, Liège, pp. 209-226.

- 2001. "Tra monumenti, agalmata e mirabilia: Organizzazione del percorso urbano di Corinto nella Periegesi di Pausania," in Knoepfler and Piérat 2001, pp. 185202.

Pemberton, E. G. 2003. "Classical and Hellenistic Pottery from Corinth and Its Athenian Connections," in Corinth XX, pp. 167-179.

Philadelpheus, A. 1926. "Аv $\alpha \sigma \kappa \alpha \varphi \alpha i ́$

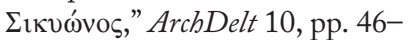
50.

Piérart, M. 2001. "Observations sur la structure du livre ii de la Périégèse: Argos, l'Argolide, et la Thyréatide," in Knoepfler and Piérat 2001, pp. 203-221.

Pirenne-Delforge, V. 2008. Retour à la source: Pausanias et la religion grecque (Kernos Suppl. 20), Liège.

Porter, J. I. 2001. "Ideals and Ruins: Pausanias, Longinus, and the Second Sophistic," in Alcock, Cherry, and Elsner 2001, pp. 63-92. 
Pretzler, M. 2004. “Turning Travel into Text: Pausanias at Work," GaR 51, pp. 199-216.

- 2007a. "Greek Intellectuals on the Move: Travel and Paideia in the Roman Empire," in Travel, Geography, and Culture in Ancient Greece, Egypt, and the Near East (Leicester Nottingham Studies in Ancient Society 10), ed. C. Adams and J. Roy, Oxford, pp. 123-138.

- 2007b. Pausanias: Travel Writing in Ancient Greece (Classical Literature and Society), London.

Pritchett, W. K. 1985. Studies in Ancient Greek Topography 5, Berkeley.

- 1999. Pausanias Periegetes 2 (Archaia Hellas 7), Amsterdam.

Radet, G. 1901. L'bistoire et l'oeuvre de l'École française d'Athènes, Paris.

Reardon, B. P. 2008. "Lucian: A True Story," in Collected Ancient Greek Novels, ed. B. P. Reardon, Berkeley, pp. 619-649.

Robert, C. 1909. Pausanias als Schriftsteller: Studien und Beobachtungen, Berlin.

Romano, D. G. 1993. "Post-146 в.c. Land Use in Corinth and Planning of the Roman Colony of 44 в.c.," in The Corinthia in the Roman Period, Including the Papers Given at a Symposium Held at the Ohio State University on 7-9 March 1991 (JRA Suppl. 8), ed. T. E. Gregory, Ann Arbor, pp. 9-30.

Romano, I. B. 1994. "A Hellenistic Deposit from Corinth: Evidence for Interim Period Activity (14644 в.с.)," Hesperia 63, pp. 57-104.

Roux, G. 1958. Pausanias en Corinthie (Livre II, 1 à 15): Texte, traduction, commentaire archéologique et topographique (Annales de l'Université de Lyon, series 3, Lettres 31), Paris.

Saïd, S. 1994. "Lucien ethnographe," in Lucien de Samosate. Actes du colloque international de Lyon organisé au Centre d'études romaines et galloromaines les 30 septembre-1 $1^{\text {er }}$ octobre 1993 (Centre d'études romaines et gallo-romaines n.s. 13), ed. A. Billaut, Lyon, pp. 149-170. . 2005. "The Mirage of Continuity: On the Uses and Abuses of Analogy in Some Travel Narratives from the Seventeenth and Eighteenth
Century," in Rethinking the Mediterranean, ed. W. V. Harris, Oxford, pp. 268-293.

Sanders, G. D. R. 2009. "Platanistas, the Course, and Carneus: Their Places in the Topography of Sparta," in Sparta and Laconia: From Prebistory to Pre-Modern, ed. W. G. Cavanagh, C. Gallou, and M. Georgiadis, London, pp. 195-203.

Shanks, M. 1992. Experiencing the Past: On the Character of Archaeology, London.

1996. Classical Archaeology of Greece: Experiences of the Discipline, London.

Shear, T. L. 1937. "The Campaign of 1936," Hesperia 6, pp. 333-381.

Shear, T. L., Jr. 1981. "Athens: From City-State to Provincial Town," Hesperia 50, pp. 356-377.

Skalet, C. H. 1928. Ancient Sicyon, with a Prosopographia Sicyonia (Johns Hopkins University Studies in Archaeology 3), Baltimore.

Snodgrass, A. M. 1987. An Archaeology of Greece: The Present State and Future Scope of a Discipline (Sather Classical Lectures 53), Berkeley. - 2003. "Another Early Reader of Pausanias?” JHS 123, pp. 187-189.

Spencer, T. 1954. Fair Greece, Sad Relic: Literary Philhellenism from Shakespeare to Byron, London.

Steinhart, M. 2002. "Tyrannenhaus und Kaiserkult: $\mathrm{Zu}$ einer angeblich römerfeindlichen Bemerkung bei Pausanias," Thetis 9, pp. 95-96.

Stibbe, C. M. 1989. "Beobachtungen zur Topographie des antiken Sparta," BABesch 64, pp. 61-99.

Sutton, S. B. 2001. "A Temple Worth Seeing: Pausanias, Travelers, and the Narrative Landscape at Nemea," in Alcock, Cherry, and Elsner 2001, pp. 175-189.

Swaddling, J. 1979. “The British Museum Bronze Hoard from Paramythia, North-Western Greece: Classical Trends Revived in the 2nd and 18th Centuries A.D.," in Bronzes bellénistiques et romaines: Tradition et renouveau. Actes du $V^{e}$ Colloque international sur les bronzes antiques, Lausanne 8-13 mai 1978, ed. C. Bérard, P. Ducrey, and A. Altherr-Charon, Lausanne, pp. 103-106.
Swain, S. 1996. Hellenism and Empire: Language, Classicism, and Power in the Greek World, A.D. 50-250, Oxford.

Thomas, R. 2000. Herodotus in Context: Ethnography, Science, and the Art of Persuasion, Cambridge.

Thompson, H. A. 1962. The Athenian Agora: A Guide to the Excavation and Museum, 2nd ed., Athens.

Tolias, G. 2007. "Pausanias in Modern Times," in Following Pausanias: The Quest for Greek Antiquity, ed. M. Georgopoulou, C. Guilmet, Y. A. Pikoulas, K. S. Staikos, and G. Tolias, Athens, pp. 57-73.

Torelli, M. 2001. "Reflections on Context," in Alcock, Cherry, and Elsner 2001, pp. 53-56.

Ulman, B. L., and P. A. Stadter. 1972. The Public Library of Renaissance Florence: Niccolò Noccoli, Cosimo de' Medici, and the Library of San Marco (Medioevo e umanesimo 10), Padua.

Vanderpool, E. 1949. "The Route of Pausanias in the Athenian Agora," Hesperia 18, pp. 128-137.

Van Dyke, R. M., and S. E. Alcock. 2003. "Archaeologies of Memory: An Introduction," in Archaeologies of Memory, ed. R. M. Van Dyke and S. E. Alcock, Malden, pp. 113.

Veyne, P. 1988. Did the Greeks Believe in Their Myths? An Essay on the Constitutive Imagination, trans. P. Wissig, Chicago.

Vingopoulou, I. 2004. Le monde grec vu par les voyageurs $d u X V I^{e}$ siècle (Collection histoire des idées 4), Athens.

Wagstaff, J. M. 2001. "Pausanias and the Topographers: The Case of Colonel Leake," in Alcock, Cherry, and Elsner 2001, pp. 190-206.

Walters, H. B. 1899. Catalogue of the Bronzes, Greek, Roman, and Etruscan, in the Department of Greek and Roman Antiquities, British Museum, London.

Waterhouse, H. 1986. The British School at Athens: The First Hundred Years (BSA Suppl. 19), London.

Watson, J. 2011. "Rethinking the Sanctuary of Aphaia," in Aegina: Contexts for Choral Lyric Poetry: Myth, History, and Identity in the 
Fifth Century B.C., ed. D. Fearn, Oxford, pp. 79-113.

Waywell, G. B., and J. J. Wilkes. 1995.

"Excavations at the Ancient Theatre of Sparta, 1992-4: Preliminary Report," BSA 90, pp. 435-460.

Wiseman, J. 1979. "Corinth and Rome I: 228 в.c. - A.D. 267, , $A N R W$ II.7.1, pp. $438-548$.

\section{Daniel R. Sterwart}

\author{
UNIVERSITY OF LEICESTER \\ SCHOOL OF ARCHAEOLOGY AND ANCIENT HISTORY \\ UNIVERSITY ROAD \\ LEICESTER LEI 7 RH \\ UNITED KINGDOM \\ ds120@1e.ac.uk
}

Wycherley, R. E. 1959. "The Temple of Hephaistos," JHS 79, pp. 153-156.

Wylie, A. 2002. "The Reaction against Analogy," in Thinking from Things: Essays in the Philosophy of Archaeology, ed. A. Wylie, Berkeley, pp. 136-153.

Yerasimos, S. 1991. Les voyageurs dans l'Empire ottoman, $X I V^{e}-X V I^{e}$ siècles:
Bibliographie, itinéraires, et inventaire des lieux habités (Publications de la Société turque d'histoire, serie 7, 117), Ankara.

Zissa, C. 2006. Le iscrizioni nella Periegesi di Pausania: Commento ai testi epigrafici (Studi e testi di storia antica 16), Pisa. 